\title{
Responsabilidad sancionadora de personas jurídicas, entes sin personalidad y administradores ${ }^{(*)}$
}

\section{Disciplinary Liability of legal entities, entities without personality and administrators}

\begin{abstract}
Resumen: La responsabilidad sancionadora de las personas jurídicas, que acepta con normalidad el ordenamiento, no es una excepción a los principios de culpabilidad y de personalidad de las sanciones: se trata de una responsabilidad por acción y culpa propias de la persona jurídica. En especial, se analiza la responsabilidad de las personas jurídicas por la actuación de sus administradores. Y, asimismo, se estudian los supuestos en que el Derecho prevé ciertos complementos o matizaciones a esa responsabilidad. Sobre todo, los casos en los que se consagra la responsabilidad sancionadora de los propios administradores. Se aborda también la responsabilidad de entes sin personalidad y se ponen de relieve las ventajas y dificultades que su aplicación entraña.
\end{abstract}

Palabras Clave: Derecho Administrativo Sancionador - Sujetos Responsables - Personas Jurídicas - Entes sin Personalidad - Administradores de Personas Jurídicas

\begin{abstract}
The disciplinary liability of legal entities, which the regulation normally accepts, is not an exception to the principles of existing guilty and of personalizing the sanction: it is a liability for action and fault of the legal entity. In particular, it analyzes the liability of legal entities by the actions of their administrators. And, also, it studies the cases in which the Law provides certain complements or qualifications to that liability. Above all, the cases in which the disciplinary liability of the administrators is evident. It also addresses the liability of entities without personality and it highlights the advantages and difficulties that their application entails.
\end{abstract}

Keywords: Disciplinary Administrative Law - Responsible Entities - Legal Entities - Entities without Personality - Administrators of Legal Entities

$\left(^{*}\right) \quad$ Catedrático de Derecho Admimistrativo de la Universidad de Córdoba (España). Miembro del Grupo de investigación de la Junta de Andalucía SEJ-196. Proyecto DER2015-67695-C2-1-P (MINECO/FEDER, UE). Correo electrónico: ad1repum@ uco.es

$\left.{ }^{* *}\right)$ Nota del Editor: El artículo fue recibido el 05 de diciembre de 2016 y aprobada su publicación el 06 de diciembre del mismo año. 
Responsabilidad sancionadora de personas jurídicas, entes sin personalidad y administradores

Disciplinary Liability of legal entities, entities without personality and administrators

\section{La responsabilidad sancionadora de las personas jurídicas}

\subsection{Consagración legal y rasgos generales de esta responsabilidad \\ En Derecho Penal, se partía tradicionalmente de la irresponsabilidad de las personas jurídicas. La causa más obvia era su incapacidad para sufrir las penas de prisión, que eran las más normales, y a las que evidentemente solo se podía someter a las personas físicas; en su caso, a las que hubieran actuado por o en el seno de la persona jurídica.}

El Derecho Administrativo español siempre ha ofrecido un panorama por completo diferente ${ }^{(1)}$. Por lo pronto, las personas jurídicas sí que pueden sufrir la inmensa mayoría de las sanciones administrativas (Quintero 1991), entre las que no pueden estar las privativas de libertad (artículo 25.3 CE); más aún, son ellas, muchas veces, las únicas que pueden sufrir las sanciones previstas por las leyes (por ejemplo, cierre de establecimientos que son de su propiedad y que explotan ellas, prohibición de realizar actividades que solo ellas venían haciendo o que incluso solo ellas pueden realizar, como las de seguros, crédito (...); revocación de autorizaciones de las que ellas son titulares, etcétera). Por ello, aquí siempre se las ha considerado posibles responsables de las infracciones administrativas (sea como autoras, en cualquier modalidad de autoría, sea como partícipes en la infracción si es que está prevista la responsabilidad por participación para la concreta infracción de que se trate) ${ }^{(2)}$. Lo proclama el artículo 28.1 de la Ley 40/2015, de 1 de octubre, de Régimen Jurídico del Sector Público (en lo sucesivo, LRJSP, como antes lo hacía el artículo 130.1 de la Ley 30/1992), lo prevén específicamente multitud de leyes sectoriales y lo acepta el Tribunal Constitucional (SSTC 246/1991, 129/2003). Los rasgos de esta responsabilidad sancionadora pueden sintetizarse así:

- Se trata de una responsabilidad por acción propia de la persona jurídica, no por acción de otro, como demostraremos.

- No necesita consagración legal específica sino que se acepta para todas las infracciones administrativas ${ }^{(3)}$. Precisamente porque se trata solo de hacerlas responsables de sus propias infracciones, basta la norma que tipifica una acción y comprobar que en el caso es ella quien la ha realizado. Solo excepcionalmente, si así lo establece explícita o implícitamente la ley (por ejemplo, porque la acción típica solo la puedan realizar personas física o porque solo estas puedan sufrir la sanción prevista), cabe excluir la responsabilidad de las personas jurídicas.

- Es una responsabilidad directa y normalmente exclusiva que no requiere identificar previa ni simultáneamente a una persona física ${ }^{(4)}$.

(1) Véase B. Lozano Cutanda, voz "Persona jurídica, sujeto activo y responsable de las infracciones administrativas", en Diccionario de sanciones administrativas (Madrid: lustel, 2010), 601 y siguientes.

(2) Igual situación conoce el Derecho de la Unión Europea. Véase Adán Nieto Martín, "El Derecho sancionador administrativo comunitario", Justicia Administrativa, número extraordinario 1 (2001): 272-4. Pero no es siempre así en todos los ordenamientos. En Italia, se sigue partiendo como regla general de que la sanción solo puede imponerse a personas físicas, pero se ha admitido últimamente que las leyes sectoriales pueden prever la responsabilidad de las personas jurídicas. Véase Pasquale Cerbo, "Las sanciones administrativas en Italia: un problema de Derecho Constitucional", Documentación Administrativa 282-283, tomo II, (2008-2009): 73-4. En Alemania, se admite pero como añadida a la responsabilidad de quienes ocupan sus órganos. Véase J. Suay Rincón, Las sanciones administrativas (Bolonia: Publicaciones del Real Colegio de España, 1989), 157-60, y B. Lozano Cutanda, La extinción de las sanciones administrativas y tributarias (Madrid: Marcial Pons, 1990), 170.

(3) Hay aquí una primera diferencia con lo que ahora rige en nuestro Derecho Penal pues el artículo 31 bis 1 del Código Penal solo admite la responsabilidad de las personas jurídicas por delitos "en los supuestos previstos en este Código".

(4) En este aspecto coincide con lo que ahora dispone el artículo 31 ter 1 del Código Penal: "La responsabilidad penal de las personas jurídicas será exigible (...) aun cuando la concreta persona física responsable no haya sido individualizada (...)”. 
Manuel Rebollo Puig

- Afecta a todo tipo de personas jurídicas: sociedades mercantiles de todo género, fundaciones, asociaciones, cooperativas, iglesias, órdenes religiosas, etcétera, y hasta Administraciones ${ }^{(5)}$.

- No se altera ni se extingue ni se transmite por el hecho de que la estructura o composición u organización o propiedad de la persona jurídica cambie; mientras la persona jurídica que incurrió en infracción permanezca, ella será la responsable. No importa, por tanto, que cambien sus administradores o sus propietarios o sus miembros o sus empleados, ni siquiera en el caso de que la conducta de alguno de estos haya sido determinante en la comisión de la infracción ${ }^{(6)}$.

\subsection{La responsabilidad de las personas jurídicas como supuesta excepción a los principios de personalidad y de culpabilidad}

Sobre esa diferencia tradicional incuestionable entre el Derecho Penal y el Derecho Administrativo, la doctrina tendió a afirmar diferencias teóricas mucho más profundas y trascendentales.

Según la dogmática penal clásica y dominante, las personas jurídicas, no es solo que no fueran responsables de los delitos que cometieran, sino que no cometían ni podían cometer delitos. Ello porque no podían realizar una acción en el sentido que a esa expresión se le atribuye en la teoría del delito y, menos aún, tener culpabilidad(7). Lo expresaba el aforismo societas delinquere non potest. Por tanto, imponerles una pena sería imponérsela a quien no ha cometido la acción típica ni ha incurrido en culpa o dolo propios. Serían así lo mismos principios de personalidad de las penas y de culpabilidad los que exigirían la irresponsabilidad penal de las personas jurídicas. Esta no sería una simple opción legislativa ni el mero fruto de que las penas

Véase Manuel Gómez Tomillo e Iñigo Sanz Rubiales. Derecho Administrativo sancionador. Parte general. Teoría general y práctica del Derecho Penal Administrativo, 2a ed. (Aranzadi, 2010), 289.

(5) Véase, sobre todo, D. Vera Jurado, "Las sanciones entre Administraciones públicas", Justicia Administrativa número extraordinario 1 (2001): 53-74; B. Lozano Cutanda, voz "Persona jurídica, sujeto activo y responsable de las infracciones administrativas", en Diccionario de sanciones administrativas (Madrid: Iustel, 2010), 612-6; Manuel Gómez Tomillo e Iñigo Sanz Rubiales. Derecho Administrativo sancionador. Parte general. Teoría general y práctica del Derecho Penal Administrativo, 2a ed. (Aranzadi, 2010), 293-5; y M. Izquierdo Carrasco, "La culpabilidad y los sujetos responsables", en M. Rebollo Puig, L. Alarcón Sotomayor y A. Bueno Armijo, Derecho Administrativo sancionador (Valladolid: Lex Nova, 2010), 265-8. No obstante, algunas leyes excluyen la responsabilidad de Administraciones como también está previsto en el artículo 31 quinquies del Código Penal. Dejamos solo apuntada esta cuestión que merece un estudio específico.

(6) Cosa distinta son los diversos supuestos de extinción de la persona jurídica responsable de la infracción; en principio ello, como la muerte de la persona física responsable de una infracción, extingue su responsabilidad. Véase la interesante SAN de 19 de mayo de 2010 (Rec. 399/2009). Pero diversas leyes, con acierto, han establecido numerosas excepciones. Véase R. Caballero Sánchez, "Las formas de extinción de la responsabilidad administrativa", Justicia Administrativa número extraordinario 1 (2001): 130-1; B. Lozano Cutanda, voz "Persona jurídica, sujeto activo y responsable de las infracciones administrativas", en Diccionario de sanciones administrativas (Madrid: Iustel, 2010), 611-3; y Manuel Gómez Tomillo e Iñigo Sanz Rubiales. Derecho Administrativo sancionador. Parte general. Teoría general y práctica del Derecho Penal Administrativo, 2 ${ }^{\mathrm{a}}$ ed. (Aranzadi, 2010), 684-91. Incluso sería correcto que se estableciera con carácter general que la extinción de las personas jurídicas no extingue la responsabilidad sancionadora. Sin entrar en este tema, que merece un estudio específico, debe notarse al menos que el artículo 130.2 del Código Penal establece que "la transformación, fusión, absorción o escisión" de una persona jurídica no extingue su responsabilidad penal, que se trasladará a la entidad o entidades en que se transforme, quede fusionada o absorbida y se extenderá a la entidad o entidades que resulten de la escisión". Habría sido muy oportuno que una norma similar se hubiera introducido en la LRJSP.

(7) Siendo esta incapacidad de acción y de culpa de la persona jurídica la premisa, se concluía que no podía ser responsable porque si se le impusiera una pena se vulnerarían los principios de culpabilidad y de personalidad. Pero bien creo que, con más realismo, las cosas podían explicarse al revés: como la persona jurídica no puede sufrir las penas privativas de libertad, que solo cabe imponer a las personas físicas, se pensó, para salvar los principios de culpabilidad y de personalidad, que quien realizaba la acción típica y tenía culpa era la persona física que actuaba por la jurídica. Además de que todo esto no 


\author{
Responsabilidad sancionadora de personas jurídicas, entes sin \\ personalidad y administradores \\ Disciplinary Liability of legal entities, entities without personality and \\ administrators
}

más importantes eran inadecuadas para las personas jurídica, sino algo consustancial al Derecho Penal, a los principios de personalidad y culpabilidad y al mismo concepto de delito.

Aceptando este planteamiento, al ver que las personas jurídicas sí son responsables de las infracciones, algunos autores tendieron a concluir que en Derecho Administrativo sancionador no rigen los principios de personalidad y de culpabilidad o, por lo menos, que tienen una enorme excepción respecto a las personas jurídicas ${ }^{(8)}$. Eso supondría una diferencia radical entre el Derecho Penal y el Derecho Administrativo sancionador, entre el delito y la infracción administrativa: aquel sería acción culpable; esta ni es acción en sentido estricto ni es verdaderamente culpable. No, al menos, cuando de las personas jurídicas se trata. Como mínimo ante estas, el Derecho Administrativo sancionador "se rige por un sistema de responsabilidad puramente objetiva"(9).

\subsection{Rechazo de la anterior tesis}

Hay que rechazar por completo la construcción expuesta que parte de postulados artificiosos y que no se acomoda a nuestro Derecho ni lo refleja ni explica fielmente.

Por lo pronto, no es la que aceptan normalmente los tribunales ${ }^{(10)} y$, en particular, no es la que aceptó la STC 246/1991: allí se admitió la responsabilidad sancionadora de las personas jurídicas, no porque no rigiesen en Derecho Administrativo sancionador los principios de personalidad y de culpabilidad o como una excepción a ellos, sino porque admitió que estas personas también tienen capacidad de acción, o sea de realizar infracciones, y de culpa $^{(11)}$.

creaba grandes problemas para los delitos clásicos, este razonamiento se acompañó de una serie de artificios tautológicos como definir a la acción exclusivamente como "comportamiento humano" y a la culpa "en clave bio-psicológica". Así todo aparentemente encajaba; pero encajaba a base de trampas conceptuales y hasta de ficciones y acrobacias como la que refleja el artículo 31.1 del Código Penal. Véase las interesantes observaciones de J. M. Zugaldía Espinar, La responsabilidad criminal de las personas jurídicas, de los entes sin personalidad y de sus directivos (Valencia: Tirant lo Blanch, 2013), 61, que además pone de relieve la incoherencia que suponía admitir, al mismo tiempo y sin grandes objeciones, que las personas jurídicas sí cometían y sí eran responsables de las infracciones administrativas.

(8) Sobre todo, se ha insistido en la falta de culpabilidad. Y ello, ya no solo por la doctrina penal clásica, sino por los administrativistas. Véase A. Nieto, Derecho Administrativo sancionador, $5^{\text {a }}$ ed. (Madrid: Tecnos, 2012), 391 y siguientes; y, sobre todo, 401-3 y 428, donde simplemente afirma que a las personas jurídicas no se les exige culpabilidad y que ello está "fuera de duda". Para R. Parada, Derecho Administrativo, II, Régimen jurídico de la actividad administrativa, $22^{\mathrm{a}}$ ed. (Madrid: Open, 2015), 398-9, la responsabilidad de las personas jurídicas es "una excepción al principio de la necesidad del elemento de culpabilidad”. Asimismo, véase I. Pemán Gavín, El sistema sancionador español. Hacía una teoría general de las infracciones administrativas (Bacelona: Cedecs, 2000), 363-4.

(9) Así, expresamente, P. Rando Casermeiro, La distinción entre el Derecho Penal y el Derecho Administrativo sancionador (Valencia: Tirant lo Blanch, 2010), 314 señala que la "construcción administrativa de la responsabilidad de las personas jurídicas (...) obedece (...) al patrón de un tosco sistema de responsabilidad objetiva (...)"; estas personas "se rigen por un sistema de responsabilidad puramente objetiva (...)". Solo algo más moderadamente J. Cid Moliné, "Garantías y sanciones", Revista de Administración Pública 140 (1996): 154-5.

(10) Véase M. Izquierdo Carrasco, "La culpabilidad y los sujetos responsables", en M. Rebollo Puig, L. Alarcón Sotomayor y A. Bueno Armijo, Derecho Administrativo sancionador (Valladolid: Lex Nova, 2010), 264-5.

(11) Importa reproducir sus palabras: "El Derecho Administrativo admite la responsabilidad directa de las personas jurídicas, reconociéndoles capacidad infractora; esto no significa, en absoluto, que para el caso de las infracciones administrativas cometidas por personas jurídicas se haya suprimido el elemento subjetivo de la culpa, sino simplemente que ese principio se ha de aplicar necesariamente de forma distinta a como se hace respecto de las personas físicas; esta construcción distinta de la imputabilidad de la autoría de la infracción a las personas jurídicas nace de la propia naturaleza de ficción jurídica a la que responden estos sujetos, pues falta en ellos el elemento volitivo en sentido estricto, pero no la capacidad de infringir las normas a las que están sometidos. Capacidad de infracción y, por ende, reprochabilidad directa que deriva del bien jurídico protegido por la norma que se infringe y la necesidad de que dicha protección sea realmente eficaz (...)". Sobre esta sentencia, véase B. Lozano, "La responsabilidad de la persona jurídica en el ámbito sancionador administrativo (a propósito de la STC 246/1991, de 19 de diciembre)", Revista de Administración Pública 129 (1992): 223-9; y Manuel Gómez Tomillo 
Manuel Rebollo Puig

En segundo lugar, se aplican con normalidad como eximentes de la responsabilidad de las personas jurídicas por infracciones administrativas las de exclusión de la acción y las de exculpación, lo que demuestra que se exige acción y culpabilidad y que, por tanto, es falso que rija un sistema de responsabilidad objetiva.

En tercer lugar, la endeblez de estos planteamientos se evidencia con el hecho mismo de que ya había ordenamientos que venían aceptando la responsabilidad penal de las personas jurídicas, de que esa solución se ha ido extendiendo(12) y de que finalmente fue también acogida en España desde la reforma del Código Penal introducida por la Ley Orgánica $5 / 2010^{(13)}$. Por lo menos, no puede dejar de reconocerse que ya no hay a este respecto una diferencia radical entre Derecho Penal y Derecho Administrativo sancionador(14). $\mathrm{Y}$, yendo un poco más lejos, también debe reconocerse que, salvo que se

e Iñigo Sanz Rubiales. Derecho Administrativo sancionador. Parte general. Teoría general y práctica del Derecho Penal Administrativo, $2^{\mathrm{a}}$ ed. (Aranzadi, 2010), 525-8. Lo que ahora importa realzar es que esta STC reconoce explícitamente la capacidad de acción y de culpa de las personas jurídicas: no justifica su responsabilidad como una excepción a los principios de personalidad y culpabilidad sino todo lo contrario. Se le pueden criticar algunos aspectos: quizás sobran algunas de sus explicaciones y faltan otras. Así lo creo. Pero es indudable que, con total acierto, no puede verse en ella ni siquiera una relajación de los principios de personalidad y de culpabilidad.

(12) Véase J. M. Zugaldía Espinar, La responsabilidad criminal de las personas jurídicas, de los entes sin personalidad y de sus directivos (Valencia: Tirant lo Blanch, 2013), 30-2; J. Pérez Arias, Sistemas de responsabilidad penal de las personas jurídicas (Madrid: Dykinson, 2014), que se ocupa en su primer capítulo, 35 y siguientes, de los antecedentes de Derecho comparado; J. Banacloche Palao y C. Gómez-Jara Díez, Responsabilidad penal de las personas jurídicas (Madrid: La Leyactualidad, 2012).

(13) Ahora, con este panorama de Derecho positivo, son los mismos penalistas los que relativizan las tradicionales objeciones dogmáticas a la responsabilidad penal de las personas jurídicas. Véase por todos la síntesis de L. Morillas Cueva, "La cuestión de la responsabilidad de las personas jurídicas", Anales de Derecho 29 (2011): 10-5. Aun así, no son pocas las reticencias doctrinales a este reconocimiento de responsabilidad penal de las personas jurídicas. Las refleja muy bien $\mathrm{J}$. M. Palma Herrera, "El papel de los compliance en un modelo vicarial de responsabilidad penal de la persona jurídica", en Procedimientos operativos estandarizados y responsabilidad penal de la persona jurídica, coord. I. González Tapia (Madrid: Dykinson, 2014), 158-62.

(14) Afirmar, como hacemos, que ya no hay una diferencia radical no significa que no subsistan diferencias. No son fáciles de establecer porque tampoco es fácil saber exactamente qué sistema, de entre los variados capaces de fundamentar atribución de responsabilidad a las personas jurídicas, acogió nuestro Código Penal tras la Ley Orgánica 5/2010 en sus nuevos artículos 31 bis, 33.7, 66 bis y 130.2 y en qué medida ha sido alterada por la reforma introducida por Ley Orgánica 1/2015. Una completa síntesis de esos sistemas y de las interpretaciones que permitía la Ley Orgánica 1/2010 ofrece J. M. Palma Herrera, "El papel de los compliance en un modelo vicarial de responsabilidad penal de la persona jurídica", en Procedimientos operativos estandarizados y responsabilidad penal de la persona jurídica, coord. I. González Tapia (Madrid: Dykinson, 2014), 162 y siguientes. En la página 170 afirma que el Código Penal "se muestra lo suficientemente impreciso como para ofrecer dudas (...) y mantener más vivo que nunca el tradicional debate sobre la capacidad de acción o de culpabilidad de las persona jurídica". No oso entrar en ese debate, que además ha quedado afectado por la LO 1/2015, aunque sí me atrevo a decir que, al menos, es posible sostener que para lo que ahora nos ocupa (responsabilidad de la persona jurídica como consecuencia de la actuación de sus administradores) el artículo 31 bis 1.a) del Código Penal parte de la idea de que quienes realizan el delito siguen siendo personas físicas: dice que "las personas jurídicas serán penalmente responsables de los delitos cometidos (...) por sus representantes legales o por aquellos que (...) están autorizados para tomar decisiones en nombre de la persona jurídica (...)". Después, en su apartado 2 dice lo siguiente: Si el delito fuere cometido por las personas indicadas en la letra a) del apartado anterior (...)". Por tanto, se parte de que quien cometió el delito es la persona física del administrador, aunque se haga responsable también a la persona jurídica. Esta interpretación era sostenida, entre otros, por J. L. Díez Ripollés, “La responsabilidad penal de las personas jurídicas. Regulación española”, InDret, Revista para el análisis del Derecho (enero 2012): 14-9. Y, modestamente, me parece la más fiel a la literalidad del Código Penal, tanto antes como después de la reforma de 2015. Pues bien, eso no es lo que se admite en el Derecho Administrativo sancionador en el que, como ahora se verá, se parte de que es la misma persona jurídica la que realiza la acción típica. 


\author{
Responsabilidad sancionadora de personas jurídicas, entes sin \\ personalidad y administradores \\ Disciplinary Liability of legal entities, entities without personality and \\ administrators
}

afirme que esos ordenamientos, incluido ahora el nuestro, no respetan los principios de personalidad y de culpabilidad en el Derecho Penal, el hecho mismo de que las personas jurídicas sean tradicionalmente responsables de las infracciones no demuestra que el Derecho Administrativo sancionador excluya tales principios.

En cuarto lugar, hay que afirmar que si las personas jurídicas realmente no podían realizar acciones en el sentido que a ello se daba en la teoría general del delito y que si tampoco eran susceptibles de ser culpables conforme al concepto de culpabilidad de la dogmática clásica del Derecho Penal ello era y es problema de aquella teoría y de esta dogmática. No se trata de criticarlas; seguramente tendrían alguna justificación y consiguieran alguna utilidad. Más modestamente sí hay que afirmar, como mínimo, que no expresaban la única forma de entender la acción y la culpa ni la única que fuese adecuada a la esencia de las cosas, a la naturaleza frente a la supuesta artificiosidad de cualquier otra solución. De ninguna de las maneras. De hecho, el Derecho Penal se veía obligado, por su negación de la responsabilidad de las personas jurídicas, a construcciones mucho más artificiosas ${ }^{(15)}$. En suma, reconocer que las personas jurídicas no pueden realizar acciones ni ser culpables conforme al sentido que a ello se le daba en la teoría penal no significa que no sean capaces de realizar acciones y de ser culpables. Lo son. Y por eso, cuando lo son y solo cuando lo son, esto es, cuando han realizado la acción tipificada y cuando la han realizado al menos con culpa, pueden ser sancionadas ${ }^{(16)}$.

\subsection{Distinción entre responsabilidad sancionadora por actuación de los administradores y por actuación de los empleados}

Lo que hay que explicar, entonces, es cómo realizan acciones y cómo incurren en culpabilidad las personas jurídicas. A este respecto hay que introducir una distinción porque las personas jurídicas realizan acciones típicas y culpables por dos vías y cada una tiene una explicación diferente. De un lado, están los casos en que las personas jurídicas incurren culpablemente en infracción a consecuencia de la conducta de sus administradores (hablaremos aquí de administradores, pero en realidad, incluimos a todos los titulares de sus órganos, como ahora se explicará). De otro, están todos los demás casos, entre ellos, destacadamente, aquellos en que las personas jurídicas incurren en infracción culpable a consecuencia de la conducta de sus empleados. No hacer esta distinción lleva a explicaciones confusas y hasta equivocadas ${ }^{(17)}$.

(15) Se veía y se sigue viendo obligado a esas construcciones artificiosas en tanto que la responsabilidad penal de las personas jurídicas solo se admite para ciertos delitos. Entre tales artificios, por ejemplo, el que refleja el artículo 31 del Código Penal que atribuye al administrador de las personas jurídicas cualidades que solo concurren en esta. Véase Manuel Rebollo Puig, Potestad sancionadora, alimentación y salud pública (Madrid: Ministerio para las Administraciones Públicas, 1989), 608-12, aunque referido al que entonces era el artículo 15 bis del Código Penal a la sazón vigente.

(16) Véase B. Lozano Cutanda, voz "Persona jurídica, sujeto activo y responsable de las infracciones administrativas", en Diccionario de sanciones administrativas (Madrid: lustel, 2010), 602-5.

(17) Pese a ello, muchas veces no se hace esta distinción que consideramos imprescindible. El mismo Tribunal Constitucional no la ha hecho. Se detecta ya en la STC 246/1991, esto es, la primera sentencia constitucional sobre responsabilidad sancionadora de las personas jurídicas: versaba sobre infracciones de personas jurídicas por actuaciones, más bien omisiones, de sus empleados. Sin embargo, sus argumentos para justificar la responsabilidad societaria solo sirven, creo yo, para justificar su responsabilidad por actos de sus representantes y directivos. Es lo que en el fondo detectó y criticó B. Lozano, "La responsabilidad de la persona jurídica en el ámbito sancionador administrativo (a propósito de la STC 246/1991, de 19 de diciembre)", Revista de Administración Pública 129 (1992): 227. Esta distinción necesaria sí está presente en E. Carbonell Porras, Régimen jurídico-administrativo del transporte interurbano por carretera (Madrid: Universidad Complutense/Univesidad de Córdoba, 1993), 439-40; R. Pizarro Nevado, "La responsabilidad personal por infracciones administrativas", en Estudios penales y jurídicos. Homenaje al Prof. Dr. Enrique Casas Barquero, coord. J. J. González Rus (Córdoba: Universidad de Córdoba, 1996); véase A. de Palma del Teso, El principio de culpabilidad en el Derecho Administrativo sancionador (Madrid: Tecnos, 1996), 202-6. 
Manuel Rebollo Puig

Solo la primera vía, la de las infracciones cometidas a consecuencia de la conducta (por acción u omisión) de sus administradores, es específica de las personas jurídicas.

La segunda, esto es, la de los restantes casos, incluidos los de infracciones a consecuencia de la conducta de los empleados, no es específica de las personas jurídicas, pese a lo que suele decirse. Es común a cualquier organización que tenga empleados aunque su titular sea una persona física: esa persona física también puede incurrir en infracciones (y en delitos) a consecuencia de las conductas de sus empleados. En cuanto a ello, no hay ninguna singularidad de las personas jurídicas.

Así que lo único que tenemos que explicar ahora es la responsabilidad de las personas jurídicas a consecuencia de la actuación de sus administradores. Su responsabilidad a consecuencia de las actuaciones de los empleados merece un análisis separado y, en realidad, común para personas físicas y jurídicas. Digamos aquí solo que para declarar lícitamente la responsabilidad sancionadora de un empleador (persona física o jurídica) por infracciones en las que la actuación material sea de sus empleados tiene que suceder, de un lado, que sea aquel quien ha realizado la acción u omisión típica y, de otro, que lo haya hecho con dolo o culpa propios. Así, tampoco habrá ahí vulneración de los principios de personalidad y culpabilidad.

\subsection{La responsabilidad de las personas jurídicas como consecuencia de la actuación de sus administradores es responsabilidad por acción y culpa propias}

Para afirmar la capacidad de acción y de culpa de las personas jurídicas a consecuencia de la conducta de sus administradores no hay que inventar grandes cosas. Basta con aceptar lo que acepta el Derecho en todas sus ramas, salvo en el Derecho Penal (rectius, salvo en algunos Derechos Penales, ya ni siquiera el nuestro, o mejor aún, salvo en la dogmática penal clásica de algunos países). O sea, que no hay que inventar nada sino rechazar ciertos inventos penalistas. Se trata solo de aplicar la teoría general de la persona jurídica y, por ende, del órgano, de la imputación orgánica. Solo de eso.

Lo que sucede sencillamente y lo que explica esta responsabilidad es que las personas jurídicas actúan mediante órganos y esos órganos tienen, entre otros elementos, el subjetivo de uno o varios titulares -personas físicas- que imputan, dentro de ciertos límites, su voluntad a la persona jurídica. Eso es todo. Así que, no es que las personas jurídicas sufran sanciones por las infracciones cometidas por quienes las administran, dirigen o representan ${ }^{(18)}$, sino por infracciones cometidas por ellas mismas. No es tampoco que pechen con la culpa de otro, sino con la suya propia. No cabe hablar de dos voluntades o de dos culpas distintas: la de la persona jurídica es la de los titulares de sus órganos y no tiene otra; no, al menos, ad extra; no, desde luego, en sus relaciones con la Administración. Por eso, en Derecho Administrativo sancionador, como en el Derecho Administrativo en general (incluido a estos efectos el Tributario, e igual que

(18) Esa es una forma equivocada de explicar el fenómeno, aunque luzca en alguna ley. Estaba ya en el Reglamento de Disciplina Urbanística de 1978, artículo 58: "Las personas jurídicas serán sancionadas por las infracciones cometidas por sus órganos o agentes (...)". Y de ahí ha pasado a muchas de las leyes autonómicas; por ejemplo, artículo 250.3 de la Ley $5 / 2014$ de la Ley valenciana de Ordenación del Territorio, Urbanismo y Paisaje; artículo 234.1.c) del TR de la Ley del Suelo de Murcia (Real Decreto legislativo 1/2005). Pero es seguro que no es que sus "órganos o agentes" comentan una infracción urbanística de la que se hace responsable a la persona jurídica, sino de que esta, que será la promotora, la contratista, la empresaria de la obra, etcétera, habrá cometido una infracción y, precisamente por eso, responderá. Son más correctos, entre otros, los artículos 193.4.a) y 194.2 de la Ley de Ordenación Urbanística de Andalucía que hablan de la "persona jurídica autora de la infracción", de "las personas físicas que desde los órganos de dirección (...) determinaron con su conducta la comisión de la infracción" o de "administradores cuya conducta haya sido determinante de que las personas jurídicas incurrieran en la infracción". Véase M. Rebollo Puig, "Las infracciones urbanísticas y sanciones", en Derecho urbanístico de Andalucía, dirs. A. Jiménez-Blanco Carrillo de Albornoz y M. Rebollo Puig, y coord. J. Cuesta Revilla (Valencia: Tirant lo Blanch, 2003), 669-71. 


\author{
Responsabilidad sancionadora de personas jurídicas, entes sin \\ personalidad y administradores \\ Disciplinary Liability of legal entities, entities without personality and \\ administrators
}

sucede en Derecho Civil, Mercantil, Laboral (...)), la persona jurídica tiene capacidad de acción y de culpa, como tiene buena o mala fe o confianza legítima o derechos humanos ${ }^{(19)}$ y tantos otros atributos de las personas físicas sin que en ello se haya visto nada sorprendente. Esas personas físicas no son nada más que los titulares de órganos de la persona jurídica y, en consecuencia, la voluntad y la culpa de esta es irremisiblemente la de aquellas ${ }^{(20)}$.

Ni siquiera tiene sentido hablar de culpa in eligendo o in vigilando de la persona jurídica sobre sus administradores. ¿Tendría sentido hablar de culpa in eligendo o in vigilando de un municipio sobre su alcalde? Pues no mucho, más razonable es en el caso de otras personas jurídicas. A fin de cuentas, quien habría elegido o vigilado mal a esos titulares serían los titulares de otros órganos de la entidad, con lo que el problema de la imputación a la persona jurídica seguiría sin resolver. Tampoco se trata de imputar a la persona jurídica un defecto de organización o una reacción insuficiente que hayan posibilitado la comisión de la infracción por las personas físicas que nutren sus órganos ${ }^{(21)}$. De nuevo, esos defectos estructurales de la entidad se deberían a las personas físicas y de nuevo quedaría sin explicación su traslado a la persona jurídica. Todo eso es inexacto $y$, además, sobra.

La simple aplicación de la teoría de la persona jurídica y del órgano explica que las personas jurídicas cometen, ellas mismas y no las personas físicas de sus administradores, acciones típicas con voluntad y culpa propias. Justifica su responsabilidad, es decir, que se imponga a ellas, no a las personas físicas que ocupan sus órganos, la sanción. Y evidencia que no hay en ello ninguna vulneración ni excepción a los principios de personalidad y culpabilidad(22), sino exactamente lo que mejor se concilia con ellos y con el significado general de las personas jurídicas en todo el ordenamiento(23).

(19) Por paradójico y hasta sarcástico que sea, como critican agudamente F. Marcos y A. Sánchez Graells, "En contra del reconocimiento de 'derechos humanos corporativos' en los procedimientos sancionadores en materia de defensa de la competencia”, en Estudios sobre la potestad sancionadora en Derecho de la Competencia, dirs. J. Guillén Caramés y M. Cuerdo Mir (Cizur Menor: Civitas, 2015), 387 y siguientes.

(20) A este respecto A. Nieto, Derecho Administrativo sancionador, $5^{\text {a }}$ ed. (Madrid: Tecnos, 2012), 393, se refiere a la imputación orgánica de que se habla en Derecho público. En efecto, la doctrina del órgano explica, en términos de L. Cosculluela Montaner, Manual de Derecho Administrativo, 25ª ed. (Civitas), 148, "la imputación jurídica de la voluntad de las personas físicas que son miembros de los órganos internos con capacidad para determinar la voluntad de esa persona jurídica en la que se integran". Por lo demás, esta es la explicación que luce en el artículo 9.3 de la Ley vasca de la Potestad Sancionadora: "Cuando la eventual responsable sea una persona jurídica, el juicio de culpabilidad se hará respecto de la persona o personas físicas que hayan formado la voluntad de aquella en la concreta actuación u omisión que se pretenda sancionar". Véase I. López Cárcamo e I. Lasagabaster Herrarte, "Artículo 9. Autoría", en Ley de la Potestad Sancionadora. Comentario sistemático, coord. Lasagabaster (Bilbao: IVAP, 2006), 198.

(21) Esa es, sin embargo, la explicación acogida por parte de la doctrina. Véase Manuel Gómez Tomillo e Iñigo Sanz Rubiales. Derecho Administrativo sancionador. Parte general. Teoría general y práctica del Derecho Penal Administrativo, $2^{a}$ ed. (Aranzadi, 2010), 529 y siguientes. Entiendo, por el contrario, que como máximo eso puede aceptarse para la responsabilidad por hechos de los empleados, no por los hechos de los administradores.

(22) Acaso sí sea más problemático desde esta perspectiva el artículo 31 bis del Código Penal, véase J. L. Díez Ripollés, "La responsabilidad penal de las personas jurídicas. Regulación española", InDret, Revista para el análisis del Derecho (enero 2012): 6-7, aunque en relación con la redacción anterior a la reforma introducida por Ley Orgánica 1/2015. De hecho, ese artículo 31 bis.1.a) habla de "delitos cometidos (...) por sus representantes legales o por aquellos que, actuando individualmente o como integrantes de un órgano de la persona jurídica (...)". Es decir, que parte de que el delito lo han cometido esas personas físicas, aunque hace responsable a la persona jurídica. No es así como debe entenderse la responsabilidad de las personas jurídicas en el Derecho Administrativo sancionador que salva más limpiamente las objeciones.

(23) Véase Manuel Rebollo Puig, Potestad sancionadora, alimentación y salud pública (Madrid: Ministerio para las Administraciones Públicas, 1989), 607-12; y M. Rebollo Puig, "Comentario al artículo 34. Sujeto activo de las infracciones de consumo", en Comentarios a la Ley General para la Defensa de los consumidores y usuarios, coords. R. Bercovitz y J. Salas (Madrid: Civitas, 1992), 935-7. 


\section{Manuel Rebollo Puig}

La explicación dada también permite sacar otras consecuencias importantes. Principalmente, las siguientes:

- Queda acotado lo que desde esta perspectiva hay que considerar acciones de la persona jurídica: solo la de quienes sean titulares de verdaderos órganos, no la de otros sujetos que trabajen por cualquier título para la persona jurídica, aunque eventualmente sean titulares de meras unidades organizativas internas ${ }^{(24)}$. Lo que importa es la relación orgánica, no la relación de servicio. Hablamos de administradores pero, aunque aceptable, es una expresión inexacta: nos referimos a personas que ocupan sus órganos; llámeseles directivos, gestores, miembros de órganos colegiados, representantes o como se quiera, incluso autoridades, si se trata de personas jurídico-públicas.

- Si los administradores actuaron con dolo, dolosa será la infracción de la entidad, y no culposa por no elegir o no vigilar bien a sus directivos; si estos incurrieron solo en negligencia, la infracción de la persona jurídica será solo culposa; y si en aquellos no se detecta ni negligencia (por ejemplo, por error invencible para lo que cabe exigir al administrador) lo mismo habrá que predicar de la entidad que, consecuentemente, no será responsable ${ }^{(25)}$.

- No importará que el administrador haya dejado de ocupar cualquier puesto en la entidad o que incluso haya fallecido. Lo único relevante es que en el momento de la infracción ocupase el órgano de la entidad y determinase su voluntad, conducta y culpa. Ni siquiera se eximirá de responsabilidad la persona jurídica por el hecho de que, precisamente por el comportamiento que llevó a la entidad a cometer una infracción, se le haya cesado en el cargo ${ }^{(26)}$.

- La sanción habráque imponerla atendiendo a las circunstancias de la persona jurídica que solo en parte están condicionadas por la de sus administradores: será reincidente, en su caso, la persona jurídica, con independencia de que en las infracciones anteriores no hayan sido determinantes las conductas de los mismos directivos ${ }^{(27)}$; habrá que atender a la situación económica de la entidad en los casos en que las leyes hacen depender de ello la cuantía de las multas, etcétera.

- Por lo general, no será necesario averiguar quién fuese la concreta persona física gestora que en cada caso propició que la persona jurídica cometiera la infracción. Ni siquiera, a diferencia de lo que sucede en Derecho Penal, es necesario que haya actuado en provecho de la persona jurídica (Quintero 1991)(28),

(24) Claro está que, como ya hemos dicho, la persona jurídica también puede cometer infracciones por las conductas de sus empleados. Pero para justificarlo hay que acudir a otras explicaciones que ya son comunes a las personas físicas que tengan empleados, según hemos adelantado.

(25) En la misma dirección, Manuel Gómez Tomillo e Iñigo Sanz Rubiales. Derecho Administrativo sancionador. Parte general. Teoría general y práctica del Derecho Penal Administrativo, $2^{a}$ ed. (Aranzadi, 2010), 395-9. Incluso creo que hay que sostener que si el administrador es inimputable, la persona jurídica será irresponsable. En otro plano, también es discutible lo que suceda con las causas de justificación. J. M. Zugaldía Espinar, La responsabilidad criminal de las personas jurídicas, de los entes sin personalidad y de sus directivos (Valencia: Tirant lo Blanch, 2013), 91 distingue según la causa de justificación sea propia de la persona física o de la persona jurídica; por ejemplo, estado de necesidad de aquella o de esta. Pero no creo que sea necesaria tal diferenciación en Derecho Administrativo sancionador.

(26) STS de 5 de noviembre de 1998 (Rec. 4971/1992).

(27) Véase M. Izquierdo Carrasco, "La determinación de la sanción administrativa”, Justicia Administrativa número extraordinario 1 (2001): 248, aunque propone alguna corrección.

(28) Basta, como explican Manuel Gómez Tomillo e Iñigo Sanz Rubiales, Derecho Administrativo sancionador. Parte general. Teoría general y práctica del Derecho Penal Administrativo, $2^{a}$ ed. (Aranzadi, 2010), 363-5, que se trate de comportamientos que "solo puedan adquirir sentido en el contexto social", o sea, en el de la entidad, sin que sea "decisivo el criterio de la actuación a favor o en interés de la empresa". Por el contrario, el artículo 31 bis.1.a) del Código Penal requiere que el representante o administrador haya actuado "en beneficio directo o indirecto" de la persona jurídica. 


\author{
Responsabilidad sancionadora de personas jurídicas, entes sin \\ personalidad y administradores \\ Disciplinary Liability of legal entities, entities without personality and \\ administrators
}

ni esta se eximiría de responsabilidad probando que el administrador actuó en contra de las instrucciones de otros órganos sociales.

\subsection{Matizaciones a la responsabilidad exclusiva de las personas jurídicas; en especial, responsabilidad del sujeto dominante}

Justificar la responsabilidad sancionadora de las personas jurídicas, afirmar que respeta los principios de personalidad y culpabilidad y reconocer sus ventajas no es óbice para confesar también que dificulta que las sanciones puedan cumplir siempre y bien sus funciones, ni la retributiva ni la preventiva; dicho de otra forma, puede conducir a algunas injusticias en tanto que eventualmente hará recaer el perjuicio sobre algunos inocentes y puede que los sujetos que realmente han llevado a cometer la infracción no vean en una sanción que no van a sufrir personalmente ni una neutralización ni un estímulo disuasorio ${ }^{(29)}$. Ante ello, está el remedio de la acción de regreso de la persona jurídica contra sus administradores (o, en su caso, contra empleados u otros sujetos) mediante la cual podrían exigirle la reparación de los daños y perjuicios causados, incluidos los que sean consecuencia de la sanción padecida. Pero, además, algunas leyes establecen mecanismos complementarios en los que acaso podría verse algo similar al levantamiento del velo de la personalidad.

El primero y fundamental es el de establecer la responsabilidad sancionadora de los administradores. Admite variantes (acumulativa y alternativa; directa e individual o solidaria o subsidiaria) que analizaremos posteriormente (epígrafe 3).

En tanto que las personas jurídicas (como las físicas) también cometen infracciones a consecuencia de las conductas de sus empleados, asimismo se conocen supuestos en que se hace responsable a estos con diversas modalidades ${ }^{(30)}$.

El tercer mecanismo es el de hacer responsable directo al que podemos llamar sujeto dominante (que podría ser una persona física o jurídica) de la persona jurídica que ha incurrido en la infracción. El supuesto más claro es el del accionista único o mayoritario

(29) Con frecuencia puede suceder que los accionistas o miembros o simples beneficiarios de la persona jurídica, que nada tuvieron que ver con la infracción, se vean perjudicados por la sanción. Lo puso de relieve B. Lozano, "La responsabilidad de la persona jurídica en el ámbito sancionador administrativo (a propósito de la STC 246/1991, de 19 de diciembre)", Revista de Administración Pública 129 (1992): 213. No se viola así el principio de personalidad porque no se les impone a ellos la sanción y lo que sufren, cabe decir, son efectos colaterales (como el que sufre el hijo del condenado a prisión). En "Los principios de legalidad, personalidad y culpabilidad en la determinación de los responsables de las infracciones", en Régimen jurídico básico de las Administraciones públicas. Libro homenaje al Profesor Luis Cosculluela (Madrid: lustel, 2015), 861-4, he destacado la diferencia entre ser sancionado y sufrir consecuencias de la sanción, así como que esto último no está condicionado por los principios de culpabilidad y responsabilidad. Pero aun así puede verse alguna injusticia. Y esta puede ser más palmaria en ciertos casos; por ejemplo, si la persona jurídica ha tomado medidas contra sus administradores, si estos (por estar intervenida la persona jurídica) eran de nombramiento judicial o administrativo, o si la sociedad ha cambiado por completo ya no solo de administradores sino de accionistas. Piénsese en este supuesto: el Sr. A, dueño de un bar, comete una infracción muy grave contra la salud pública a la que corresponde una sanción de 100.000 euros. Aunque venda el bar al Sr. B, la Administración sancionará al Sr. A y no se producirá ninguna injusticia. Pero si el Sr. A hubiera constituido una sociedad $X$ y fuese esta la titular del bar, y si el traspaso del bar se hiciera mediante la venta de todas las acciones del Sr. A al Sr. B, se sancionaría a la sociedad X porque formalmente nada ha cambiado y, desde luego, nada habrá cambiado para la Administración sancionadora. Pero quien realmente sufriría la sanción sería el Sr. B, que es por completo inocente, mientras que el Sr. A saldría indemne, todo lo cual supone una injusticia palmaria y sangrante.

(30) Puesto que hemos dejado para otra ocasión el estudio de la responsabilidad de empleadores por conductas de sus empleados, dejemos ahora también al margen esta posibilidad de hacer responsable a ambos. Citemos solo el ejemplo del artículo 17.5 de la Ley 28/2015 de Calidad Alimentaria. 
Manuel Rebollo Puig

o que, al menos, tiene una participación significativa ${ }^{(31)}$, pero puede presentar muchas otras variedades respecto a fundaciones, entes públicos (...) Algunas leyes consagran esta responsabilidad ${ }^{(32)}$, que está especialmente asentada en el Derecho de la competencia(33). A decir verdad, no lo hacen de la misma forma ni es siempre fácil saber exactamente lo que consagran. Aquí, donde no procede un estudio sectorial, solo ofreceremos el marco general con algunas pinceladas:

a) No puede admitirse sin previsión legal específica. $\mathrm{Ni}$ siquiera cabe aceptarla por la vía de entender que el miembro dominante en el caso concreto ha sido el autor de la infracción por tener el dominio del hecho ni aun por servirse de la persona jurídica como mero instrumento ${ }^{(34)}$. Si eso se aceptara llevaría simultáneamente a no sancionar a la persona jurídica que realizó la infracción ya que sería un mero instrumento del autor o, por lo menos, habría que negarle el dominio del hecho, o sea, la condición de autor. Y ello sería muy inconveniente (permitiría a la Administración imputar a uno u otro sujeto a su albur y hasta permitiría a los otros miembros de la persona jurídica alegar que debe sancionarse solo a alguno) y teóricamente injustificado. Una persona

(31) Algunas leyes definen lo que entienden por participación significativa. Así, artículos 16 y siguientes de la Ley 10/2014 de Ordenación, Supervisión y Solvencia de Entidades de Crédito; artículo 85 de la Ley 20/2015 de Ordenación, Supervisión y Solvencia de las Entidades Aseguradoras y Reaseguradoras; artículo 174 del Texto Refundido de la Ley del Mercado de Valores de 2015. Y ese concepto tiene diversas consecuencias, entre otras, por lo que aquí interesa, consecuencias en cuanto a la responsabilidad sancionadora de la persona con participación significativa por las infracciones de la entidad participada.

(32) Así lo hace la Ley 10/2014 de Ordenación, Supervisión y Solvencia de Entidades de Crédito en sus artículos 89.2 y 96.3 ; la Ley de Dinero Electrónico de 2011 en su artículo 23.1; etcétera. Asimismo, la Ley 20/2015 de Ordenación, Supervisión y Solvencia de las Entidades Aseguradoras y Reaseguradoras establece en su artículo 190 varios supuestos de sujetos responsables de los que ahora nos ocupan y entre ellos el de "las personas físicas o entidades que sean titulares de participaciones significativas en entidades aseguradoras o reaseguradoras". Y, con frecuencia, uniendo la posibilidad de hacer responsables a los administradores y la de hacer responsables a las sociedades dominantes, se hace responsables de las infracciones a los administradores de la sociedad dominante. Así está previsto para las infracciones de las entidades de crédito y expresamente el artículo 157.3 del TR de la Ley de Sociedades de Capital (R. Decreto Legislativo 1/2010) que hace responsable a "los administradores de la sociedad dominante que haya inducido a cometer la infracción". Nótese que se considera que la sociedad dominante no ha cometido la infracción sino que ha inducido a cometerla.

(33) El artículo 61.2 de la Ley de Defensa de la Competencia dice que "la actuación de una empresa es también imputable a las empresas o personas que la controlan, excepto cuando su comportamiento económico no venga determinado por alguna de ellas". En general, el Derecho de la competencia es especialmente proclive a la responsabilidad de las sociedades matrices. Lo sintetiza bien la Sentencia Sasol y otros/Comisión, T-541/08, EU:T:2014:628: "en lo referente a la responsabilidad solidaria de una sociedad matriz por la conducta de su filial o de una empresa común en la que participa (...) el hecho de que una filial o una empresa común tenga personalidad jurídica distinta no basta para excluir la posibilidad de imputar su comportamiento a la sociedad matriz (...) En efecto, el Derecho de la competencia de la Unión tiene por objeto las actividades de las empresas, y el concepto de empresa comprende cualquier entidad que ejerza una actividad económica, con independencia del estatuto jurídico de esa entidad y de su modo de financiación (...) El concepto de empresa designa una unidad económica aunque, desde el punto de vista jurídico, esta unidad económica esté constituida por varias personas físicas o jurídicas (...) Por consiguiente, puede resultar necesario determinar si dos o varias sociedades que tienen personalidades jurídicas separadas constituyen o forman parte de una misma y única empresa o entidad económica que desarrolla un comportamiento único en el mercado", apartados 29-31. De conformidad con lo anterior, la Sentencia recuerda que "el comportamiento de una filial puede imputarse a la sociedad matriz, a causa de su pertenencia a una misma empresa, cuando esa filial no determina de manera autónoma su conducta en el mercado porque la sociedad matriz ejerce una influencia decisiva sobre ella en ese aspecto, teniendo en cuenta concretamente los vínculos económicos organizativos y jurídicos que unen a esas dos entidades jurídicas", aparatado 33.

(34) Sobre la aceptación de esas figuras en el Derecho Administrativo sancionador, véase M. Rebollo Puig, "Responsabilidad de los autores de las infracciones y de los partícipes", Revista Vasca de Administración Pública 99-100, vol. III (2014): 2529-30. 


\author{
Responsabilidad sancionadora de personas jurídicas, entes sin \\ personalidad y administradores \\ Disciplinary Liability of legal entities, entities without personality and \\ administrators
}

jurídica es titular de relaciones jurídicas (también de relaciones de Derecho público) y centro de imputación de derechos y deberes (también deberes públicos). Lo es y debe serlo siempre, incluso las de menos sustrato real (como una sociedad de único socio). Si el levantamiento del velo debe tener límites so pena de arruinar el mismo significado y utilidad de las personas jurídicas, más todavía ha de tenerlos en el Derecho Administrativo sancionador. Y si este parte de la capacidad de acción y de culpa de las personas jurídicas y de su responsabilidad, tiene que aceptarlo con todas sus consecuencias ${ }^{(35)}$.

b) Las leyes que consagran expresamente esta responsabilidad así como las resoluciones que las apliquen han de cumplir ciertas condiciones. Solo cabe sancionar al miembro dominante en el supuesto de que en el caso concreto haya realizado una conducta propia con dolo o culpa propios. Esa conducta tiene que ser de autoría (porque tenga el dominio del hecho o porque incluso sea el autor mediato) o de participación (por ejemplo, inducción) en la concreta infracción. Por tanto, no bastará con que tenga en general una influencia poderosa sobre la persona jurídica que materialmente realizó la acción típica o con que sea propietaria de todo su capital o con que sea su filial $(\ldots)^{(36)}$. A lo sumo, esto permitirá presumir que también tuvo el dominio en el caso concreto, pero naturalmente esa presunción podrá desvirtuarse ${ }^{(37)}$. Cualquier otra solución, además de crear más problemas de los que

(35) Por eso es acertada, por ejemplo, la STSJ de Murcia de 26 de marzo de 2003 (Ar. 425) que anuló la sanción impuesta a un Ayuntamiento por la infracción que había cometido una sociedad de capital íntegramente municipal. Discutible al menos es la STS de 7 de julio de 2003 (Ar. 4593) que confirmó tres sanciones por los mismos hechos, dos impuestas a dos personas jurídicas y la tercera al socio único de ambas, en aplicación de la Ley del Mercado de Valores. La sentencia parece basarse en una responsabilidad por tratarse de cooperadores necesarios pero, además de que la cooperación necesaria no es autoría en sentido estricto y de que solo puede sancionarse con expresa previsión legal, lo cierto es que aquí se levantó el velo de la personalidad sin fundamento en una ley. Además, por así decirlo, se levantó el velo a medias dando origen a una acumulación de sanciones difícilmente conciliable con el non bis in ídem.

(36) Véase J. M. Baño León, Potestades administrativas y garantías de las empresas en el Derecho español de la competencia (Madrid: McGraw-Hill, 1996), 257-8. Por ello, con razón, insiste J. Costas Comesaña, "Notas sobre el ámbito de aplicación del concepto de unidad económica en el Derecho de la competencia", en Cuestiones actuales del procedimiento sancionador en el Derecho de la Competencia, dir. J. Guillén Caramés (Civitas, 2013), 222-4, en que la responsabilidad de la sociedad de control que permite la legislación de defensa de la competencia no es "un supuesto de responsabilidad por la conducta de otro, sino una responsabilidad por hecho propio".

(37) Esta es la idea que late en el antes transcrito artículo 61.2 de la Ley de Defensa de la Competencia y la que efectivamente se aplica. Lo demuestra J. M. Sala Arquer, "La responsabilidad de la matriz por la conducta contraria a la competencia de una sociedad filial: una perspectiva desde el Derecho Administrativo sancionador", en Cuestiones actuales del procedimiento sancionador en el Derecho de la Competencia, dir. J. Guillén Caramés (Civitas, 2013), 201-3 y 210-2. Igualmente M. Araujo, "Sujetos responsables y procedimiento sancionador", en la misma obra colectiva, 236. Véase también J. Costas Comesaña, "Notas sobre el ámbito de aplicación del concepto de unidad económica en el Derecho de la competencia", en Cuestiones actuales del procedimiento sancionador en el Derecho de la Competencia, dir. J. Guillén Caramés (Civitas, 2013), 218-23 que afirma que se trata de una presunción iuris tantum que admite prueba en contrario. Una presunción, por cierto, que no se considera contraria a la presunción de inocencia. Así lo entiende la Sentencia del Tribunal de Justicia FLS Plast/Comisión, C-243/12 P, EU:C:2014:2006. La Comisión basó la responsabilidad solidaria en la presunción de que una entidad matriz que posee el $100 \%$ del capital de una entidad filial ejerce un control efectivo sobre esta en sus decisiones en el mercado. Se impugnó la decisión por contraria a la presunción de inocencia. El Tribunal recuerda que "esta presunción [de control efectivo] resulta de reiterada jurisprudencia del Tribunal de Justicia (véase, en particular, la sentencia The Dow Chemical Company/Comisión, C-179/12 P, EU:C:2013:605, apartado 56 y jurisprudencia citada)" y reitera que "la aplicación de tal presunción no constituye en modo alguno una violación de la presunción de inocencia (...) habida cuenta, en particular, de su carácter de presunción iuris tantum (véase, en especial, la sentencia Eni/Comisión, C-508/11 P, EU:C:2013:289, apartado 50 y jurisprudencia citada)", apartado 27 . Señala que es posible romper esta presunción, por ejemplo, cuando la empresa matriz acredita que la filial ha actuado de manera independiente en el mercado. $Y$ aclara que "el mero hecho de que sea 
Manuel Rebollo Puig

resuelve, es contraria a los principios de personalidad o de culpabilidad. Por eso, si es que no son inconstitucionales varias de las leyes que establecen esta responsabilidad, pueden serlo las resoluciones que se dicten en su virtud sin respetar estos requisitos.

c) De ninguna forma sería oportuno que las leyes sectoriales continuaran extendiendo esta solución. Menos aún que una ley la acogiera con carácter general ni siquiera para los casos de abuso de la personalidad pues erosiona, por no decir que dinamita, los cimientos sobre los que está construida la responsabilidad de las personas jurídicas. Cosa muy distinta sería que se estableciera la simple responsabilidad solidaria o subsidiaria de estos miembros dominantes respecto del pago de las sanciones pecuniarias impuestas a la persona jurídica ${ }^{(38)}$, o que se les declare responsables en caso de disolución de la persona jurídica. Esto resuelve muchísimo mejor los problemas que suscita el abuso de la personalidad sin dañar al sistema en su conjunto. $Y$, puestos a superar la ficción de la personalidad y a "levantar el velo", sería preferible, por ser más real y más fácil, que se acogiese la posibilidad de sancionar al conglomerado empresarial como uno de esos entes sin personalidad a los que eventualmente se considera autores y responsables de infracciones.

No agotan estas responsabilidades de administradores, de empleados o de miembros dominantes todas las posibilidades y a veces aparecen instrumentos sui generis para evitar o paliar el excesivo formalismo y rigor a que puede conducir la responsabilidad de las personas jurídicas como el de la
Ley andaluza de Defensa del Consumidor de 2003 que permite la condonación de las sanciones cuando "la empresa infractora haya pasado a estar controlada por otros accionistas, propietarios o gestores después de cometerse la infracción" (artículo 93). Solución similar acoge ahora el artículo 276 del Texto Refundido de la Ley del Mercado de Valores de 2015 que asimismo permite condonar las sanciones impuestas a personas jurídicas "cuando hayan pasado a estar controladas por otros accionistas después de cometerse la infracción (...) o se den otras circunstancias excepcionales que hagan que el cumplimiento de la sanción (...) atente contra la equidad (...)". Seguramente valdría la pena explorar este tipo de soluciones para que pueda aflorar la equidad entre tanto formalismo.

Otra matización a la exclusiva responsabilidad sancionadora de las personas jurídicas, ya más extraña y discutible, se puede producir cuando, por un mismo hecho, se sanciona administrativamente a la persona jurídica y, además, se condena penalmente a sus administradores o, en su caso, a sus empleados. El TC acepta ahora esta acumulación sin ver en ella, por no existir identidad de sujetos, una vulneración del non bis in ídem ${ }^{(39)}$.Sin llegar a sostener la

difícil aportar la prueba en contrario necesaria para destruir una presunción no implica, en sí mismo, que esta sea una presunción iuris et de iure (véase, en particular, la sentencia Eni/Comisión, EU:C:2013:289, apartado 68 y jurisprudencia citada)", apartado 30.

(38) Es lo que, como responsabilidad subsidiaria, está previsto en el artículo 43.1.g) y h) de la Ley General Tributaria ante los que M. A. Martínez Lago, "La extensión de la responsabilidad a las sanciones tributarias", en La responsabilidad de los administradores de sociedades de capital, coord. G. Guerra Marín (Madrid: La Ley, 2011), 655-7, habla de "responsabilidad por levantamiento del velo de la personalidad jurídica".

(39) Así, STC 70/2012 que, a su vez, cita en esa misma dirección los AATC 355/1991 y 357/2003. Pero mantuvo una postura contraria la STC 177/1999. Defienden que esto no es contrario al non bis in ídem Manuel Gómez Tomillo e Iñigo Sanz Rubiales, Derecho Administrativo sancionador. Parte general. Teoría general y práctica del Derecho Penal Administrativo, $2^{a}$ ed. (Aranzadi, 2010), 231-2. Parten, como nosotros, de que las personas jurídicas son sancionadas administrativamente por una acción y culpa propios. Pero entienden, y en ello discrepo, que se trata de una acción y de una culpa distintas de la de su administrador y que entre ambos se daría una situación similar a la de la coautoría o participación. Es importante la STS de 31 de marzo de 2010 (Casación para unificación de doctrina No. 457/2008) que admitió también penas a las personas físicas y sanciones administrativas a la persona jurídica. 


\author{
Responsabilidad sancionadora de personas jurídicas, entes sin \\ personalidad y administradores \\ Disciplinary Liability of legal entities, entities without personality and \\ administrators
}

tesis radicalmente contraria ${ }^{(40)}$, sí creo que se trata de un fenómeno patológico que si acaso cabría admitir cuando sea deliberadamente querido por el ordenamiento que dé a cada castigo un fundamento distinto, no como fruto casual de la existencia de dos normas punitivas que castigan realmente lo mismo. Sin estas matizaciones se pueden producir injusticias evidentes, así como reales vulneraciones del non bis in ídem mediante argumentos artificiosos y puramente formalistas ${ }^{(41)}$.

\section{Responsabilidad sancionadora de entidades sin personalidad jurídica}

Como regla general, solo las personas físicas y jurídicas pueden ser consideradas autoras (o partícipes) y responsables de las infracciones. Quedan excluidas, por tanto, cualesquiera entes sin personalidad. Incluso algunas leyes lo aclaran de una u otra forma. Es el caso de la Ley de Pesca Marítima de 2001 cuyo artículo 90.1 establece que "son responsables de las infracciones tipificadas en esta Ley las personas físicas o jurídicas que las cometan, aun cuando estén integradas en asociaciones temporales de empresas, agrupaciones o comunidades de bienes sin personalidad". Estos entes sin personalidad, por tanto, no son responsables ni su existencia exime de responsabilidad a las personas que se integran en ellas. Es lo mismo que más directamente dice el artículo 52.3 de la Ley de Seguridad Aérea de 2003: "No eximirá de responsabilidad el hecho de que las personas que hayan cometido las infracciones estén integradas en asociaciones temporales de empresas, agrupaciones de interés económico o comunidades de bienes sin personalidad"(42). Aunque las leyes no contengan reglas como estas, hay que afirmar que, salvo previsión legal específica, estos entes no pueden ser considerados ni autores ni responsables de las infracciones en ningún concepto(43).

(40) Ha sido defendida con argumentos distintos e interesantes por L. Alarcón Sotomayor, La garantían non bis in ídem y el procedimiento administrativo sancionador (Madrid: lustel, 2008), 43-4; por B. Feijoo Sánchez, Sanciones para empresas por delitos contra el medio ambiente (presupuestos dogmáticos y criterios de imputación para la intervención del Derecho Penal contra las empresas) (Madrid, 2002), 59-66; y por M. Pérez Manzano, La prohibición constitucional de incurrir en bis in ídem (Valencia: Tirant lo Blanch, 2002), 127 y siguientes. Además, también alguna vez ha sido acogida por los Tribunales; además de por la ya aludida STC 177/1999, por la STSJ de Murcia, Apelación 500/2010.

(41) El que partamos de reconocer que las personas jurídicas son sancionadas administrativamente por una acción y culpa propias no permite decir que se pueda también penar al administrador por su acción y su culpa. No, porque lo que sucede, como hemos explicado, es que la acción y culpa del administrador, como titular de un órgano, son las de la entidad. No hay dos acciones y dos culpas. Son la misma y, ante ello, o bien se opta por la ficción de la persona jurídica y se castiga a esta, o bien se opta por prescindir de la ficción y se castiga a la persona física que actúa por ella. Pero no las dos cosas. Como máximo se puede estar dispuesto a aceptar que el ordenamiento haya querido penar a las personas físicas y sancionar a la jurídica por entender que solo así se consigue captar toda la antijuridicidad y culpabilidad, que solo así se consiguen efectivamente los fines de los castigos; acaso entonces puedan descubrirse fundamentos distintos para cada uno de los castigos. Ello al igual que sucede cuando algunas leyes prevén, como veremos luego, sanciones administrativas tanto para la persona jurídica como para sus administradores. Pero lo que sucede normalmente con la pena a la persona física y la sanción administrativa a la jurídica es una carambola no querida por el ordenamiento que lleva, en conjunto, a castigos desproporcionados e injustos. Ello de forma especialmente sangrante cuando se trate de pequeñas sociedades, incluso de un único socio que podrá sufrir dos castigos. Se trata realmente de concursos de normas en los que hay que aplicar solo una porque hay un único hecho y un único fundamento. En el fondo, también, un único sujeto, aunque determinado de forma distinta por el Derecho Penal y por el Administrativo. La aceptación ahora de la responsabilidad penal de las personas jurídicas reducirá el problema, pero no lo excluirá.

(42) En el fondo, la misma solución, aunque con algún matiz, es la que acogen otras leyes. Por ejemplo, la Ley de Semillas y Plantas de Vivero y de Recursos Fitogenéticos de 2006: "En el supuesto de herencias yacentes, comunidades de bienes y demás entidades que, carentes de personalidad jurídica, constituyen una unidad económica o un patrimonio separado, serán responsables solidarios los copartícipes o cotitulares, en proporción a sus respectivas participaciones" (artículo 58.2).

(43) De conformidad con ello, la STSJ de Madrid de 17 de junio de 2010 (Rec. No. 372/2009) anuló el precepto de una Ordenanza de limpieza que atribuía la responsabilidad de las infracciones a las comunidades de propietarios por considerarlo contrario al artículo 130.1 de la Ley 30/1992 y a los principios de personalidad y culpabilidad. 
Manuel Rebollo Puig

La solución, en principio, parece la más lógica: si no tienen personalidad no puede entenderse que hayan cometido el ilícito ni que sean responsables de él. En su caso, lo serán cada una de las personas físicas o jurídicas cotitulares de la comunidad de bienes o que integren una agrupación de cualquier tipo. Lo que sí sucederá muchas veces es que se estará en el supuesto previsto en el artículo 28.3 LRJSP (antes en el artículo 130.3.1 de la Ley 30/1992): "Cuando el cumplimiento de las obligaciones previstas en una disposición legal corresponda a varias personas conjuntamente (...)", de suerte que, conforme a ese precepto, podrá establecerse solidaridad entre ellas.

Pero algunas leyes dieron un paso más. El modelo lo ofrecía la legislación tributaria. La premisa se encuentra ahora en el artículo 35.4 de la Ley General Tributaria (en adelante, "LGT") a cuyo tenor "tendrán la consideración de obligados tributario, en las Leyes en que así se establezca, las herencias yacentes, comunidades de bienes y demás entidades que, carentes de personalidad jurídica, constituyan una unidad económica o un patrimonio separado susceptibles de imposición". Sobre esa base, el artículo 181.1 LGT incluye a estas entidades sin personalidad entre los "sujetos infractores" cuando "realicen las acciones u omisiones tipificadas como infracciones". Otro ejemplo señero es el del TR de la Ley de Infracciones y Sanciones en el Orden Social cuyo artículo 2 comienza por afirmar que "son sujetos responsables de la infracción las personas físicas o jurídicas y las comunidades de bienes que incurran en las acciones $u$ omisiones tipificadas como infracción (...)". Asimismo, consagra esta solución el artículo 53 de la Ley General de Subvenciones ${ }^{(44)}$, el artículo 56.2 de la Ley del Servicio Postal Universal de 2010(45), el artículo 17 de la Ley de la Calidad Alimentaria de 2015, el artículo 11.1 de la Ley de Represión del Contrabando, etcétera, y alguna ley autonómica(46).
Ante ello, la LRJSP ha optado por incorporar en su artículo 28.1 la posibilidad de que sean sancionados "los grupos de afectados, las uniones y entidades sin personalidad jurídica y los patrimonios independientes o autónomos" pero solo "cuando una Ley les reconozca capacidad de obrar". Así concuerda con el artículo 3.c) de la nueva Ley de Procedimiento Administrativo Común que admite que estos entes sin personalidad tengan capacidad de obrar ante la Administración "cuando una Ley así lo declare". Nótese que se exige una norma con rango de ley (de "Ley" con mayúscula se habla en ambos preceptos) pero que, en realidad, no exige que esa ley les reconozca la condición de autores y responsables de infracciones sino solo que les reconozca capacidad de obrar. Parece, pues, que basta esto para que automáticamente puedan ser considerados autores de infracciones y sufrir sanciones.

No puede dejar de vislumbrarse algo misterioso en esta responsabilidad de entes sin personalidad. En todas las leyes vistas que ya hacían responsables a estos entes, solo a ellos, y no a sus miembros o partícipes, se impondrá la sanción. $Y$ se hace así porque se considera que son ellos los que han cometido la infracción: se les incluye entre los sujetos infractores, se dice que incurren en infracción o expresiones similares. Ahora parece que el fenómeno se hará más común. Pero no es fácil explicar cómo se atribuye capacidad de acción y de culpabilidad a quienes carecen

(44) Véase M. Rebollo Puig y M. Izquierdo Carrasco, "El régimen de infracciones y sanciones", en Comentario a la Ley General de Subvenciones, dir. G. Fernández Farreres (Madrid: Thomson/Civitas, 2005), 618-20.

(45) Dice que "la responsabilidad administrativa por las infracciones (...) se exigirá a las personas naturales o jurídicas, así como a las herencias yacentes, comunidades de bienes y demás entidades carentes de personalidad jurídica que cometan cualesquiera de las infracciones tipificadas (...)".

(46) Por ejemplo, artículo 193.5 de la Ley de Ordenación Urbanística de Andalucía de 2002: "También podrán ser sancionadas las entidades y uniones sin personalidad jurídica, tales como comunidades de bienes o herencias yacentes, cuando la infracción consista en la transgresión de deberes o de prohibiciones cuyo cumplimiento les corresponda". Véase M. Rebollo Puig, "Las infracciones urbanísticas y sanciones", en Derecho urbanístico de Andalucía, dirs. A. Jiménez-Blanco Carrillo de Albornoz y M. Rebollo Puig, y coord. J. Cuesta Revilla (Valencia: Tirant lo Blanch, 2003), 459-64. 


\author{
Responsabilidad sancionadora de personas jurídicas, entes sin \\ personalidad y administradores \\ Disciplinary Liability of legal entities, entities without personality and \\ administrators
}

de personalidad. Puede decirse que esto supone aceptar una ficción similar a la de la personalidad jurídica aunque solo en ciertos sectores del ordenamiento. Hay, cabría decir, un fenómeno inverso al del levantamiento del velo de la personalidad jurídica: donde no hay tal personalidad, teniendo en cuenta que hay una realidad similar, se opera casi como si la hubiera. Y con ese presupuesto quizás quepa decir de la acción y de la culpabilidad de estos entes lo mismo que hemos dicho de las personas jurídicas, pero con el problema añadido de que aquí frecuentemente ni siquiera nos encontraremos con verdaderos órganos ni con titulares de los órganos que propiamente imputen sus decisiones y actuaciones al ente.

Al margen de esos problemas teóricos, la aceptación de la responsabilidad de las entidades sin personalidad suscita otras cuestiones. Al menos cuatro. Por lo pronto hay que delimitar exactamente qué tipo de entidades pueden tener este tratamiento. Algunas leyes señalan con precisión qué genero de estos entes puede ser considerado responsable ${ }^{(47)}$, pero, cuando no haya especificaciones legales de este género, resultará dudoso, sobre todo ahora con el genérico artículo 28.1 LRJSP, si podrán ser incluidas entre los responsables a uniones temporales de empresas, a agrupaciones de interés económico, a sociedades irregulares o en constitución, a cualquier copropiedad (...) En segundo lugar, es problemático determinar en qué supuestos pueden ser consideradas autoras y responsables pues parece excesivo que lo que haga cualquiera de los individuos (por ejemplo, cualquiera de los copropietarios de un bien) pueda imputarse a la entidad y generar su responsabilidad. En tercer lugar, también hay que resolver si se responderá únicamente con el patrimonio común de los partícipes, como si fuese ese el equivalente al patrimonio de una sociedad infractora, o si responderán también estos con su patrimonio individual(48). Por último, aun admitiendo que solo debe ser considerada interesada en el procedimiento sancionador la entidad sin personalidad(49), hay que resolver quién interviene por ella. Desde luego, lo que no tiene sentido es que el procedimiento hubiera de entenderse con todos los miembros o partícipes pues ello desvirtuaría el sentido de estas previsiones legales. Con esa premisa, parece razonable aceptar como solución general la del artículo 45.3 LGT según el cual actuará en representación de estas entidades "el que la ostente, siempre que resulte acreditada en forma fehaciente y, de no haberse designado representante, se considerará como tal el que aparentemente ejerza la gestión o dirección y, en su defecto, cualquiera de sus miembros o partícipes".

Reconocidas las objeciones teóricas y los problemas prácticos, lo cierto es que la solución de hacer responsables de infracciones a entes sin personalidad se ha ido extendiendo y ahora, con el impulso del artículo 28.1 LRJSP, se hará más normal. Y ello con justificación pues soluciona razonablemente bien problemas reales y habituales, sobre todo en algunos sectores. Piénsese en los muchos

(47) Así, por ejemplo, el antes aludido artículo 17 de la Ley de Calidad Alimentaria solo se refiere a la posible responsabilidad sancionadora, junto a personas físicas y jurídicas, de las comunidades de bienes. Hay que entender que ningún otro tipo de los entes sin personalidad, aunque estén aludidos en el artículo 28.1 LRJSP, puede ser responsable de las infracciones previstas en esa Ley.

(48) Así lo he argumentado en "Las infracciones urbanísticas y sanciones", en Derecho urbanístico de Andalucía, dirs. A. JiménezBlanco Carrillo de Albornoz y M. Rebollo Puig, y coord. J. Cuesta Revilla (Valencia: Tirant lo Blanch, 2003), 463-4. Alguna ley tiene previsiones específicas. Por ejemplo, el artículo 42.1.b) LGT prevé, además de la responsabilidad de la entidad, la responsabilidad solidaria de "los partícipes o cotitulares (...) en proporción a sus respectivas participaciones"; la Ley del Servicio Postal Universal establece en su artículo 57.3 que son "responsables solidarios los partícipes o cotitulares de las entidades sin personalidad".

(49) Hay que aceptar a estos efectos la capacidad y la legitimación del ente sin personalidad lo que, aunque resulte chocante, concuerda con los artículos 3.c) LPAC y $18.2^{\circ}$ y 19.1.b) LJCA que reconocen capacidad procesal y legitimación a las "uniones sin personalidad o patrimonios independientes o autónomos, entidades todas ellas aptas para ser titulares de derechos y obligaciones, al margen de su integración en las estructuras formales de las personas jurídicas (...) cuando la Ley así lo declare expresamente". 
Manuel Rebollo Puig

casos en los que la infracción consiste en la inobservancia de deberes que incumben a todos los copropietarios, a todos los herederos, a todos los miembros de otro tipo de agrupaciones o a unidades económicas reconocibles aunque no tengan el manto de la personalidad. Y repárese en que, si no se acoge la responsabilidad de estos entes sin personalidad, la alternativa es, conforme al artículo 28.3 LRJSP, la de hacer responsables solidarios de la infracción a todos y cada uno los miembros del grupo, lo que suscita objeciones teóricas y dificultades prácticas incluso de mayor alcance ${ }^{(50)}$. Por otra parte, en algunos casos ciertas sanciones (por ejemplo, las que consisten en cierre de establecimientos o prohibición de realizar una actividad) y sobre todo ciertas medidas correctoras (realizar tareas de conservación, demoler obras ilegales, etcétera) solo cobran pleno sentido imponiéndolas a estas entidades. De hecho, hasta el Derecho Penal se ha tenido que enfrentar a esta realidad de los entes sin personalidad(51). Incluso en ámbitos como el del Derecho de la competencia podría prestar buenos servicios ${ }^{(52)}$. Y hasta se observa

(50) Acertadamente ya señaló A. de Palma del Teso, El principio de culpabilidad en el Derecho Administrativo sancionador (Madrid: Tecnos, 1996), 102, que la solución del artículo 28.3 LRJSP (entonces contenida en el artículo 130.3.1 de la Ley 30/1992) pretende sobre todo "dar solución al problema que se plantea cuando se impone una obligación legal a una agrupación de personas o entes sin personalidad jurídica". De hecho, alguna ley, cuando niega la capacidad infractora y responsabilidad sancionadora a los entes sin personalidad, acoge expresamente la de la solidaridad entre todos los miembros. Es ejemplo claro de ello el antes citado artículo 58.2 de la Ley 30/2006 de Semillas y Plantas de Vivero y de Recursos Fitogenéticos. Pero hacer responsables solidarios de la infracción a todos y cada uno de los miembros de un grupo no solo hace surgir los reparos teóricos de todo ese género de responsabilidades solidarias (criticadas por la doctrina y hasta por la jurisprudencia) sino que plantea dificultades prácticas notables pues obliga a tramitar un procedimiento en que todos ellos sean interesados y a probar la conducta personal y culpable de cada uno de ellos. ¿Cómo se hace eso con, por ejemplo, una comunidad de propietarios de la Ley de Propiedad Horizontal? Sin duda es preferible desde casi todos los puntos de vista partir de la capacidad de cometer infracción y de ser responsable de ella de la comunidad.

(51) En nuestro ordenamiento, se plasma en el artículo 129 del Código Penal (modificado por Ley Orgánica 1/2015). En realidad, ni considera que estos entes cometan delitos ni prevé para ellos penas. Pero sí que permite que, además de la pena que corresponda a alguno de los sujetos que en él se integran, se les impongan consecuencias accesorias a la pena tales como suspensión de actividades, clausura de locales, inhabilitación para obtener ayudas públicas o contratar (...) Véase, aunque con referencia a la redacción anterior a la reforma de 2015, J. M. Zugaldía Espinar, La responsabilidad criminal de las personas jurídicas, de los entes sin personalidad y de sus directivos (Valencia: Tirant lo Blanch, 2013), 170-7. Desde luego, la solución es muy distinta a la que estamos viendo que acogen algunas leyes para infracciones y sanciones administrativas, pero pone de relieve cómo en ambos órdenes estos entes sin personalidad plantean necesidades que merecen soluciones específicas.

(52) En el Derecho de la competencia, se resuelven problemas similares haciendo responsable de la infracción de una entidad (la filial) a la persona jurídica dominante (la matriz), como hemos visto antes. No hay en ello, o no lo hay necesariamente si se aplica bien, violación del principio de responsabilidad personal, como ya hemos explicado. Pero quizás todo sería más lógico y más conforme a la realidad de las cosas si se atribuyera la responsabilidad al conjunto que forman esas entidades, a la unidad económica aunque no tuviese personalidad. Son muy sugerentes a este respecto J. Costas Comesaña, "Notas sobre el ámbito de aplicación del concepto de unidad económica en el Derecho de la competencia", en Cuestiones actuales del procedimiento sancionador en el Derecho de la Competencia, dir. J. Guillén Caramés (Civitas, 2013), 218-26 y M. Araujo, "Sujetos responsables y procedimiento sancionador", en la misma obra colectiva, 232-7. Ponen de relieve que el Derecho de la competencia tiene por destinatarias a las empresas y que por tales se entienden cualesquiera unidades económicas aunque estén constituidas por varias personas y no exista otra persona jurídica que las englobe a todas. Con ello justifican la responsabilidad de la persona jurídica dominante. De acuerdo. Pero cabría dar un paso más: mucho mejor que declarar responsable a la matriz sería optar por la responsabilidad de esa unidad económica, o sea, por hacer responsable a un ente sin personalidad jurídica, como aquí estamos viendo que se hace ya en otras ramas del ordenamiento y que posibilita el artículo 28.1 LRJSP. En el mismo Derecho europeo, se observa la tendencia a "elaborar un concepto fáctico y no jurídico de sujeto activo", como explica Adán Nieto Martín, "El Derecho sancionador administrativo comunitario", Justicia Administrativa, número extraordinario 1 (2001): 273 y ese concepto fáctico bien podría reflejarse en la asunción de responsabilidad de entes sin personalidad. 


\author{
Responsabilidad sancionadora de personas jurídicas, entes sin \\ personalidad y administradores \\ Disciplinary Liability of legal entities, entities without personality and \\ administrators
}

que en ocasiones ya se había aceptado la responsabilidad sancionadora de estos entes sin personalidad pese a no contar con ninguna consagración legal(53). Recíbase, pues, favorablemente la novedad del artículo 28.1 LRJSP. Pero, como tantas veces, las soluciones a problemas originan nuevos problemas. Y lo que quizás sí quepa achacar a la LRJSP es no haber abordado de ninguna forma los problemas que la responsabilidad sancionadora de entes sin personalidad genera. Eso queda por completo confiado a las leyes sectoriales que, es de temer, acogerán soluciones injustificadamente diversas, cuando no regímenes incompletos, para una figura que requiere como mínimo un marco general común.

\section{Responsabilidad sancionadora de los administradores de las personas jurídicas}

Hemos visto cómo con normalidad las personas jurídicas son consideradas autoras y responsables de infracciones a consecuencia de la conducta de sus administradores. Generalmente ello supone la irresponsabilidad personal de sus administradores, pese a ser los que han realizado una conducta que ha llevado a la entidad a la comisión de la infracción ${ }^{(54)}$. Pero hemos anticipado asimismo que, pese a ello, a veces las leyes establecen algún género de responsabilidad sancionadora de los administradores.

A este respecto se acoge un concepto amplio de administrador. Las leyes hablan de representantes legales ${ }^{(55)}$, de personas con poder de representación, de miembros de órganos colegiados o unipersonales directivos, de quienes ostenten cargos de administración o de dirección, de quienes ejerzan funciones de alta dirección (...) a veces incluso de liquidadores. En general, se utilizan términos amplios y, aun así, se añade una vaga alusión a los cargos asimilados o similares. Sobre todo se incluye a quienes ejerzan tales funciones de hecho o de derecho ${ }^{(56)}$. Por tanto, no solo importarán los nombramientos formales para un cargo sino también las funciones reales y la posición

(53) Es lo que puede verse en STS de 15 de diciembre de 2011 (Casación No. 1275/2009) que confirma la sanción a una comunidad de propietarios por infracción de la Ley de Telecomunicaciones de 2003 pese a que esta en su artículo 51 solo preveía la responsabilidad de las personas físicas y jurídicas. Y esta sentencia ni siquiera se plantea la objeción de la falta de responsabilidad de la comunidad de propietarios. Véase también la STS de 20 de mayo de 2009 (Rec. 220/2005) sobre sanciones en materia de aguas a una comunidad de bienes.

(54) Es determinante la STS de 31 de diciembre de 2008, Casación No. 7788/2004: la responsabilidad de los administradores societarios solo resulta posible cuando así lo determinen las leyes reguladoras de los distintos sectores. Salvo tal previsión expresa por ley se sanciona a la persona jurídica y sus administradores son irresponsables. No basta el reglamento para consagrar ningún género de responsabilidad de los administradores pues se trata con claridad de uno de los aspectos cubiertos por la reserva de ley. Por eso es cuestionable la validez del artículo 9.4 del RD 1945/1983 que establece la responsabilidad por infracciones de consumo cometidas por personas jurídicas de quienes integren sus órganos rectores o de dirección. Ello, sin perjuicio de que diversas Leyes autonómicas han consagrado, ya sin ese problema de rango, tal responsabilidad. Véase M. Izquierdo Carrasco, "La incidencia del régimen sobre protección de consumidores en la responsabilidad de los administradores", en La responsabilidad de los administradores de sociedades de capital, coord. G. Guerra Marín (Madrid: La Ley, 2011), 775-9.

(55) Esa es la expresión única de la Ley 5/2014 de Seguridad Privada. Pero aclara que "representantes legales son todos aquellos que asuman o realicen las tareas de dirección, administración, gestión y representación, o cualquiera de ellas, en nombre de la empresa de seguridad" (artículo 22.1).

(56) Así dice el artículo 271.2 del Texto Refundido de la Ley del Mercado de Valores (R. Decreto Legislativo 4/2015) que a los efectos de sanciones se considera a "sus administradores o miembros de sus órganos colegiados de administración, así como sus directores generales y asimilados, entendiéndose por tales aquellas personas que, de hecho o de derecho, desarrollen en la entidad funciones de alta dirección".

La Ley 20/2015 de Entidades Aseguradoras, en su artículo 190.f) se refiere a "las personas que ejerzan la dirección efectiva, bajo cualquier título, en cualquiera de las entidades descritas en las letras anteriores o ejerzan en ella algunas de las funciones del sistema de gobierno previstas en el artículo 65.3" (gestión de riesgos, auditoría interna, etcétera). Se aclara, 
Manuel Rebollo Puig

efectiva en la entidad, de modo que estas responsabilidades alcanzarán a quienes, por la razón que sea, tengan capacidad decisoria y el dominio de la entidad o el del concreto hecho constitutivo de infracción( ${ }^{(57)}$.

En realidad, hay distintas formas de hacer responsables a los administradores. En nuestro Derecho Administrativo sancionador hay, al menos, tres.

La primera y más modesta es la de, pese a considerar infractora únicamente a la persona jurídica y sancionarla exclusivamente a ella, establecer que sus administradores serán responsables subsidiarios o solidarios del pago de las multas. De este modo, como sucede en todos los casos en que se consagra tal género de responsabilidad, los administradores simplemente vendrán obligados a satisfacer la deuda derivada de la resolución sancionadora en caso de impago del deudor principal (la persona jurídica sancionada), ya sea porque este resulte fallido (caso de la responsabilidad subsidiaria) ya sea porque sencillamente no paga en el periodo establecido (caso de la responsabilidad solidaria). Estos responsables del pago de las sanciones (que han de diferenciarse de los responsables solidarios de la infracción $\left.{ }^{(58)}\right)$ están establecidos en diversas leyes ante realidades muy diferentes. $Y$, entre ellas, por lo que ahora nos interesa, está establecida a veces para los administradores de las personas jurídicas infractoras. Ejemplo de responsabilidad subsidiaria de los administradores suministra la Ley 24/2003 de la Viña y el Vino(59); de su responsabilidad solidaria, lo da la Ley del Servicio Postal Universal ${ }^{(60)}$. Y hay ejemplos de ambas modalidades en la Ley General Tributaria(61). En todos los casos, la responsabilidad solidaria o subsidiaria no se establece por el mero hecho de ser administrador de la persona

además, que ejercen la dirección efectiva, bajo cualquier título, quienes ostenten cargos de administración y dirección en la entidad en los términos del artículo 38.2, así como quienes, sin haber sido designados formalmente, desempeñen de facto tales responsabilidades". También considera sujetos infractores a los liquidadores de las aseguradoras.

Por todo esto, a veces es necesario un análisis pormenorizado de las atribuciones que realmente tenga cada administrador para determinar si es posible atribuirle una participación. En esta línea son ilustrativas las SSTS de 26 y 27 de marzo de 2012 (Casación No. 2650 y 4087/2011) sobre responsabilidad de los administradores de compañías de seguros.

(57) Véase C. García-Herrera Blanco, "Los administradores de hecho ante la Administración tributaria", en La responsabilidad de los administradores de sociedades de capital, coord. G. Guerra Marín (Madrid: La Ley, 2011), 585 y siguientes.

(58) La distinción queda apuntada en la LRJSP que recoge un supuesto de responsables solidarios de la infracción (artículo 28.3) y prevé otros de responsables del pago de la sanción (artículo $28.4 .2^{\circ}$ ).

(59) Dice su artículo 41.4: "De las infracciones cometidas por las personas jurídicas, incluidos los órganos de gestión de los v.c.p.r.d. y los organismos u órganos de inspección o control, serán responsables subsidiariamente los administradores o titulares de los mismos que no realizaren los actos necesarios que fuesen de su incumbencia para el cumplimiento de las obligaciones infringidas, consintieren el incumplimiento por quienes de ellos dependan o adoptaren acuerdos que hicieran posibles tales infracciones". También artículo 58.4 de la Ley de Semillas, Plantas de Vivero y Recursos Fitogenético: "En los supuestos de infracciones graves o muy graves, cuando una infracción sea imputada a una persona jurídica, serán responsables subsidiarios las personas que integren sus órganos rectores o de dirección, siempre que la infracción sea imputable a su conducta dolosa o negligente". Diversas leyes autonómicas también lo establecen. Por ejemplo, la Ley andaluza 7/2006 conocida como ley antibotellón: "serán responsables subsidiarios de las sanciones impuestas a las personas jurídicas los administradores de las mismas" (artículo 11.3).

(60) Artículo 57.4: "(...) son responsables solidarios los administradores de hecho o de derecho de las personas jurídicas que no hubieran salvado su voto con ocasión del acuerdo que hubiera ocasionado la infracción".

(61) La LGT establece diferentes supuestos de responsabilidad solidaria y subsidiaria respecto de la deuda tributaria que, cuando así esté expresamente previsto, alcanza también a las sanciones (artículo 41.4). Entre los supuestos de responsables subsidiarios por sanciones está el de "los administradores de hecho o de derecho de las personas jurídicas que, habiendo estas cometido infracciones tributarias, no hubiesen realizado los actos necesarios que sean de su incumbencia para el cumplimiento de las obligaciones y deberes tributarios, hubiesen consentido el incumplimiento por quienes de ellos dependan o hubiesen adoptado acuerdos que posibilitasen las infracciones". Véase M. A. Martínez Lago, "La extensión de la responsabilidad a las sanciones tributarias", en La responsabilidad de los administradores de sociedades de capital, coord. 


\author{
Responsabilidad sancionadora de personas jurídicas, entes sin \\ personalidad y administradores \\ Disciplinary Liability of legal entities, entities without personality and \\ administrators
}

jurídica infractora sino por, además, haber realizado alguna conducta de colaboración en la infracción ${ }^{(62)}$.

En el extremo opuesto, algunas leyes han optado por atribuir exclusivamente la responsabilidad de ciertas infracciones a los administradores de personas jurídicas. En general, parece que se trata de supuestos en los que, aunque la infracción se realice con ocasión del ejercicio del cargo de administrador social, se entiende que es realmente este (no la persona jurídica) el que ha cometido la infracción ${ }^{(63)}$. Pero no cabe descartar que quepan también casos en los que, por diversas razones, se haga responsable único al administrador pese a entenderse que la infracción podría imputarse a la entidad. El caso más claro lo ofrece el Texto Refundido de la Ley de Sociedades de Capital (Real Decreto Legislativo 1/2010) respecto a las infracciones administrativas por negocios sobre las propias participaciones y acciones: "Se reputarán como responsables de la infracción a los administradores de la sociedad infractora y, en su caso, a los de la sociedad dominante (...)" (artículo 157.3) ${ }^{(64)}$.

Pero existe una tercera posibilidad, que es la más frecuente y la que sobre todo nos interesa aquí: se establece la responsabilidad sancionadora de los administradores además y sin perjuicio de la de la persona jurídica; se sanciona a la entidad y, también, en su caso, al o a los administradores; y ello con sanciones distintas. Sírvanos de ejemplo el claro y simple que ofrece el artículo 79.3 de la Ley 9/2014 de Telecomunicaciones: "Además de la sanción que corresponda imponer a los infractores, cuando se trate de una persona jurídica, se podrá imponer una multa de hasta 5.000 euros en el caso de infracciones leves, hasta 30.000 euros en el caso de infracciones graves y hasta 60.000 euros en el caso de infracciones muy graves a sus representantes legales o a las personas que integran los órganos directivos que hayan intervenido en el acuerdo o decisión". Con variantes menores, a la misma idea responden el Texto Refundido de la Ley del Mercado de Valores (R. Decreto Legislativo 4/2015)(65), la Ley 15/2007 de Defensa de la Competencia(66); la Ley 8/2003 de Sanidad

G. Guerra Marín (Madrid: La Ley, 2011), 649-51. No obstante, la misma LGT permite en algunos casos considerar que los administradores sean responsables solidarios de las personas jurídicas. Véase I. Jiménez Compaired, "Los administradores como responsables solidarios (artículo 42 LGT)", en La responsabilidad de los administradores de sociedades de capital, coord. G. Guerra Marín (Madrid: La Ley, 2011), 535 y siguientes.

(62) Además, según la jurisprudencia y la doctrina, ha de mediar dolo o culpa del administrador en su conducta de colaboración en la infracción. Véase por todos A. Cayón Galiardo, "La responsabilidad tributaria de los administradores de sociedades. Administradores de personas jurídicas que hubiesen cometido una infracción tributaria", en La responsabilidad de los administradores de sociedades de capital, coord. G. Guerra Marín (Madrid: La Ley, 2011), 485-9. Y, entre otras, SSTS de 14 y 21 de marzo de 2013 (Ar. 2765 y 2808). Tengo dudas de que ello sea necesariamente así o, dicho de otra forma, dudo que la Constitución impida supuestos de responsables subsidiarios o solidarios de las multas sin dolo o culpa. Pero no procede entrar aquí en ello. En cualquier caso, sí es seguro que solo podrán ser declarados responsables de este género los que eran administradores en el momento de cometerse la infracción. Véase A. Cayón Galiardo, Ibídem, 483-4, y G. ORÓN MORATAL, "El procedimiento para declarar y exigir la responsabilidad de los administradores", en la misma obra colectiva, 669.

(63) Así, el artículo 195.11 de la Ley de Entidades Aseguradoras de 2015 tipifica la infracción consistente en el incumplimiento por quienes hayan sido administradores en los cinco años anteriores de sus obligaciones en caso de liquidación de la entidad. Se parte, pues, de un deber que incumbe personalmente a esos administradores y, por ello, quienes cometen la infracción son ellos, no la compañía aseguradora.

(64) Véase L. C. Fernández-Espinar López, "La responsabilidad de los administradores derivada de normativa sobre las entidades de crédito, mercados de valores, entidades aseguradoras y negocios sobre las propias acciones", en La responsabilidad de los administradores de sociedades de capital, coord. G. Guerra Marín (Madrid: La Ley, 2011), 764-71. Repárese en que el transcrito artículo 157.3 habla de la sociedad infractora, es decir, que parte de que quien ha cometido la infracción es esta, pese a lo cual solo hace responsable a los administradores.

(65) Su artículo 271.1 declara genéricamente la "responsabilidad administrativa sancionable" de las personas físicas y jurídicas "así como de quienes ostenten de hecho o de derecho cargos de administración o dirección de estas últimas". Después sus 
Manuel Rebollo Puig

Animal(67); la Ley 10/2010 de Prevención del Blanqueo de Capitales $^{(68)}$; el TR de la Ley de Planes de Pensiones (R. Decreto Legislativo 1/2002; artículos 35.1 y 36.3 y 4); etcétera(69). Aunque con más dudas, creo que pueden incluirse en este grupo la Ley 10/2014 de Entidades de Crédito y la Ley 20/2015 de Entidades Aseguradoras ${ }^{(70)}$. $Y$ tal vez otras leyes que, sin embargo, han perfilado borrosamente la responsabilidad de

artículos 306 y 307 se ocupan de las "sanciones complementarias (...) a quienes ejerzan cargos de administración y dirección". El mismo nombre de sanciones complementarias es expresivo. Pero más lo es el comienzo de esos artículos: "Además de la sanción que corresponda imponer al infractor (...) cuando la infractora sea una persona jurídica, podrá imponerse una o más de las siguientes sanciones a quienes, ejerciendo cargos de administración o dirección en la misma, sean responsables de la infracción (...)". O sea, que se considera que la infractora es la persona jurídica, aunque responsables lo sean esta y sus administradores y que, por tanto, se sanciona a aquella y a estos. Véase P. Mayor Menéndez, "Sobre la responsabilidad conjunta de las personas jurídicas y sus administradores en el Derecho Administrativo sancionador (especial referencia al Mercado de Valores)", Revista Española de Derecho Administrativo 87 (1995): 353-60.

(66) Artículos 61.2 y sobre todo 63.2: "Además de la sanción prevista en el apartado anterior (es decir, las establecidas para los autores de la infracción), cuando el infractor sea una persona jurídica, se podrá imponer una multa de hasta 60.000 euros a cada uno de sus representantes legales o a las personas que integran los órganos directivos que hayan intervenido en el acuerdo o decisión". Véase J. M. Baño León, Potestades administrativas y garantías de las empresas en el Derecho español de la competencia (Madrid: McGraw-Hill, 1996), 253-6; J. C. Laguna de Paz, "La infracción de las normas de defensa de la competencia como supuesto de responsabilidad de los administradores", en La responsabilidad de los administradores de sociedades de capital, coord. G. Guerra Marín (Madrid: La Ley, 2011), 787 y siguientes. Cosa distinta, es que esta responsabilidad de los administradores, que no conoce el Derecho de la competencia europeo, sea escasamente utilizada. Véase L. Cases Pallarés, El Derecho Administrativo de defensa de la competencia (Madrid: Marcial Pons, 1995$), 217$.

(67) Artículo 86.3: "En el supuesto de infracciones graves o muy graves, cuando una infracción sea imputada a una persona jurídica, podrán ser también consideradas responsables las personas que integren sus órganos rectores o de dirección, siempre que la infracción sea imputable a su conducta dolosa o negligente, en cuyo caso podrá imponérseles la sanción prevista en el párrafo b) del apartado 1 del artículo 88", o sea, multa de 3.001 a 60.000 euros.

(68) Artículo 54: "Además de la responsabilidad que corresponda al sujeto obligado aun a título de simple inobservancia, quienes ejerzan en el mismo cargos de administración o dirección, sean unipersonales o colegiados, serán responsables de las infracciones cuando éstas sean imputables a su conducta dolosa o negligente". Los artículos $56.2,57.2$ y 59.2 precisan la sanción que hay que imponer a estos sujetos. A este respecto es interesante la STS de 10 de abril de 2014 (Casación No. 653/2012).

(69) Las leyes autonómicas también han establecido esta responsabilidad. Ejemplo, entre otros muchos, ofrece el artículo 33.4 de la Ley andaluza 2/1988 de Servicios Sociales: "Con independencia de las sanciones que puedan imponerse a las entidades titulares de los Centros, podrán también ser sancionados con inhabilitación para el ejercicio de sus funciones los representantes legítimos de las mismas responsables de la infracción por los períodos siguientes (...)".

(70) Antes, las leyes reguladores de estos sectores respondían puramente a este modelo. Véase F. González Botija, "La jurisprudencia del Tribunal Supremo sobre la responsabilidad de los cargos de administración y dirección por infracción de la Ley 26/2008, de 29 de julio, de disciplina e intervención de las entidades de crédito", en Administración y justicia. Un análisis jurisprudencial. Liber amicorum Tomás-Ramón Fernández, coords. E. García de Enterría y R. Alonso García. Tomo I (Civitas, 2012), 1285-312; y L. C. Fernández-Espinar López, "La responsabilidad de los administradores derivada de normativa sobre las entidades de crédito, mercados de valores, entidades aseguradoras y negocios sobre las propias acciones", en La responsabilidad de los administradores de sociedades de capital, coord. G. Guerra Marín (Madrid: La Ley, 2011), 692 y siguientes. Las nuevas Leyes de 2014 y 2015 son más oscuras en tanto que permiten sancionar solo a los administradores sin sancionar a la entidad. Creo, con todo, que el cambio solo obedece a que han acogido la tesis de "la accesoriedad limitada de la participación", a la que nos referimos después. Explicado así, puede entenderse que también ellas sancionan a los administradores por su participación o colaboración de infracciones de la persona jurídica. En cualquier caso, ambas prevén sanciones que solo pueden recaer sobre los administradores, como son la separación o suspensión del cargo o la inhabilitación para ejercerlos durante cierto tiempo, sin que además tipifiquen infracciones específicas para ellos. Por tanto, tales sanciones solo son imaginables ante la realización de una conducta típica cuando es realizada por la entidad a las que administran. 


\author{
Responsabilidad sancionadora de personas jurídicas, entes sin \\ personalidad y administradores \\ Disciplinary Liability of legal entities, entities without personality and \\ administrators
}

los administradores ${ }^{(71)}$. Los rasgos esenciales de esta tercera modalidad son los siguientes:

a) Se hace responsable al administrador como partícipe o colaborador en una infracción ajena de la que es autora la persona jurídica ${ }^{(72)}$.

b) Solo surge la responsabilidad de los administradores por una conducta propia de participación en la infracción de la entidad, conducta realizada, además, con dolo o negligencia del mismo administrador ${ }^{(73)}$. Y no solo debe haber una conducta culpable del administrador sino una relación entre esta y la infracción de la entidad ${ }^{(74)}$. Se comprende entonces que los responsables serán los que fueran administradores en el momento de comisión de la infracción, no los que lo sean en el momento de dictar las resolución sancionadora.

(71) Una serie de leyes, tras la reforma que introdujeron en ellas diversas disposiciones finales de la Ley 2/2011 de Economía Sostenible, proclaman ahora la responsabilidad de los administradores pero sin que sea fácil determinar a qué modalidad de las descritas responden; así, artículo 54.1 de la Ley de Mediación de Seguros y Reaseguros.

Particularmente, difícil de encasillar es la Ley 5/2014 de Seguridad Privada. Es claro que permite sancionar a las empresas de seguridad privada y a sus representantes legales. De hecho, se prevén algunas sanciones que solo pueden imponerse a estos, como la de prohibición de ser representante legal durante unos plazos. Pero formalmente la ley no establece que estos sean sancionados por su participación en la infracción de la empresa sino por una infracción propia consistente en el incumplimiento de los deberes que se imponen a esos representantes. Hasta aquí todo permitiría adscribir esta ley al de aquellas que atribuyen exclusivamente la responsabilidad de ciertas infracciones a los administradores de personas jurídicas. Pero lo sorprendente es que la infracción que por antonomasia pueden cometer estos representantes consiste en incumplir su deber de asegurar que las empresas que administran no cometen infracciones (artículo 57 en relación con el 22.3). Así las cosas, si la empresa comete una infracción, su representante comete otra, y aquella y este serán sancionados. Esto parece encajar en lo que ahora admite con carácter general el artículo 28.4.1 ${ }^{\circ}$ LRJSP: "(...) tipificar como infracción el incumplimiento de la obligación de prevenir la comisión de infracciones administrativas" por otros. Esto se compadece mal con el papel de los administradores y parece una solución innecesariamente complicada y burda que, a la postre, deja en manos de la Administración sancionar a la empresa o a su representante o a ambos con imputaciones formalmente distintas pero materialmente idénticas.

(72) Algún precepto ha apuntado precisamente en esa línea; así, la Ley castellano-leonesa 11/1998 de Defensa de los Consumidores y Usuarios hace responsables de las infracciones cometidas por personas jurídicas a sus directivos "siempre que hubieran participado en los hechos" (artículo 26.5). M. Izquierdo Carrasco, "La incidencia del régimen sobre protección de consumidores en la responsabilidad de los administradores", en La responsabilidad de los administradores de sociedades de capital, coord. G. Guerra Marín (Madrid: La Ley, 2011), 780, llega a afirmar que el administrador es sancionado como cooperador necesario; y añade que estaría en la posición de garante. Véase también B. Lozano, "La responsabilidad de la persona jurídica en el ámbito sancionador administrativo (a propósito de la STC 246/1991, de 19 de diciembre)”, Revista de Administración Pública 129 (1992): 239.

(73) Véase R. Caballero Sánchez, "Las formas de extinción de la responsabilidad administrativa”, Justicia Administrativa número extraordinario 1 (2001): 130. Son ilustrativas las SSTS de 18 de octubre de 2006 (Rec. 199/2004), de 23 de noviembre de 2008 (Rec. 202/2004). Es clara la Ley 10/2014 de Entidades de Crédito: "Quien ejerza en la entidad de crédito cargos de administración o dirección será responsable de las infracciones cuando estas sean imputables a su conducta dolosa o negligente" (artículo 104.1). Lo mismo establece el artículo 271.3.1 del Texto Refundido de la Ley del Mercado de Valores (R. Decreto Legislativo 4/2015), aunque en este caso solo se prevé la responsabilidad de administradores para infracciones graves o muy graves. Para algunas leyes, la responsabilidad del administrador solo surge si incurre en dolo; así, artículo 83.1.b) de la Ley andaluza de defensa del consumidor. Otras exigen dolo o negligencia grave; por ejemplo, artículo 32.5 de la Ley murciana de consumo. Pero, por lo general, las leyes no establecen determinaciones de este género de modo que basta cualquier grado de negligencia. Por el contrario, parece que solo se sanciona a los administradores por infracciones de defensa de la competencia cuando tienen una notable e intencionada participación. Véase J. C. Laguna de Paz, "La infracción de las normas de defensa de la competencia como supuesto de responsabilidad de los administradores", en La responsabilidad de los administradores de sociedades de capital, coord. G. Guerra Marín (Madrid: La Ley, 2011 ), 792.

(74) La STS de 8 de febrero de 1999 (Rec. 828/1995) dice que es "necesario un nexo de causalidad entre la infracción y la conducta del administrador o director"; la STS de 23 de noviembre de 1998 (Rec. 662/1996) dice que "es preciso que exista 
Manuel Rebollo Puig

c) En tanto que el administrador es responsable como partícipe en la infracción de la que es autora la persona jurídica, debe regir, salvo norma expresa, la "accesoriedad limitada de la participación"(75) que solo admite en ciertos casos que sea sancionado el partícipe sin ser sancionado el autor. En cualquier caso, sí se acepta con normalidad que se sancione a la entidad y no al administrador ${ }^{(76)}$.

d) A veces, la participación consiste en haber votado a favor del acuerdo determinante de la infracción y por ello las leyes se esmeran

una relación de causalidad entre su falta de diligencia (la del administrador) y la producción de los hechos infractores". Alguna ley lo plasma exactamente: “(...) será responsable de las infracciones (...) cuando estas sean imputables a su conducta dolosa o negligente" (así, el ya citado artículo 104.1 de la Ley de Entidades de Crédito). Lo digan o no así, esto es necesario pues lo contrario violaría el principio de personalidad de las sanciones y de culpabilidad. Cosa distinta es que a los administradores de ciertas entidades se les exija un tan amplio deber de diligencia que, ante la consumación de la infracción, normalmente habrá como mínimo una omisión negligente y rara vez pueda detectarse total inexistencia de culpa.

(75) Cuando rige la accesoriedad limitada, si el autor realiza un hecho que, aunque típico, no es antijurídico por concurrir una causa de justificación, no podrá ser sancionado ni este ni el partícipe pues no tendría sentido castigar a alguien por inducir o cooperar a un acto lícito; pero en los demás casos (falta de culpa del autor, fallecimiento de este, etcétera) el partícipe, que sí actuó culpablemente, debe sufrir la sanción. Véase sobre ello y su aplicación al Derecho Administrativo sancionador M. Rebollo Puig, "Responsabilidad de los autores de las infracciones y de los partícipes", Revista Vasca de Administración Pública 99-100, vol. III (2014): 2538. Ello permite, entre otras cosas, sancionar al administrador aunque se haya extinguido la persona jurídica infractora. En contra, M. Izquierdo Carrasco, "La incidencia del régimen sobre protección de consumidores en la responsabilidad de los administradores", en La responsabilidad de los administradores de sociedades de capital, coord. G. Guerra Marín (Madrid: La Ley, 2011), 780-1, se inclina en estos casos por la "accesoriedad máxima" que exigiría para sancionar al administrador que la autora, en nuestro caso, la persona jurídica, sea efectivamente castigada. Un revelador supuesto de accesoriedad limitada sugiere la STS de 7 de febrero de 2003 (Rec. 6265/97): ante la difícil situación financiera de la entidad y para evitar daños a terceros, aceptó que, sin sancionar a la persona jurídica, sí se sancionara a sus administradores. También puede explicarse en clave de accesoriedad limitada el artículo 65.3 de la Ley de Defensa de la Competencia que, con toda lógica, permite eximir de sanción a las personas jurídicas que colaboren con la Administración en la detección de infracciones contra la competencia y sancionar, sin embargo, a parte de sus directivos en tanto que no hayan realizado igual colaboración.

Pero sobre todo es la tesis de la accesoriedad limitada la que quizá puede explicar, como antes se anunció, la regulación de las Leyes 10/2014 y 20/2015 sobre, respectivamente, Entidades de Crédito y Aseguradores. Aun así, con algunas dificultades. La primera de esas leyes dice que las responsabilidades de las entidades de crédito y de sus administradores "serán independientes" y que "la falta de incoación de expediente sancionador o el archivo o sobreseimiento del incoado contra una entidad de crédito no afectará necesariamente a la responsabilidad en que puedan incurrir los cargos de administración y dirección de la misma, y viceversa" (artículo $89.1 .2^{\circ}$ ). La Ley $20 / 2015$ dice que los administradores y liquidadores "cuando sean los responsables de las infracciones cometidas por las entidades, podrán ser los únicos sancionados por la comisión de las mismas" (artículo 191.1). Realmente estas leyes, que perfilan mal estos supuestos, podrían entenderse en el sentido de consagrar el sistema antes aludido de atribuir exclusivamente la responsabilidad de ciertas infracciones a los administradores. Creo sin embargo que lo que mayoritariamente tratan de acoger esas reglas son supuestos de responsabilidad de los administradores por participar en infracciones de las que son autoras las entidades pero en los que, por diversas razones, estas no lleguen a ser sancionadas; o sea, como decimos, expresión de la teoría de la accesoriedad limitada. En cierto modo, se trataría de algo similar, aunque a la inversa, a lo que dispone el artículo 31 ter 1 CP que permite penar a la persona jurídica "aun cuando la concreta persona física responsable no haya sido individualizada o no haya sido posible dirigir el procedimiento contra ella". En estas Leyes 10/2014 y 20/2015 se trata de consagrar una regla semejante aunque partiendo, contrariamente a lo que hace el Código Penal, de que la verdadera autora de la infracción es la persona jurídica. En uno y otro caso lo que a la postre se permite es castigar al partícipe en la infracción aunque no se haya podido castigar al autor.

(76) Incluso en varias leyes, dando por supuesto que hay que sancionar a la persona jurídica, la imposición de sanción a los administradores aparece como potestativa e incluso sin señalar ningún criterio al que la Administración se deba de ajustar para decidir si sanciona o no a los administradores. Críticamente, J. M. Baño León, Potestades administrativas y garantías de las empresas en el Derecho español de la competencia (Madrid: McGraw-Hill, 1996), 255-6. 


\author{
Responsabilidad sancionadora de personas jurídicas, entes sin \\ personalidad y administradores \\ Disciplinary Liability of legal entities, entities without personality and \\ administrators
}

en precisar cuándo los miembros de órganos colegiados societarios comprometen su responsabilidad o se eximen de ella con su voto en contra o su inasistencia ${ }^{(77)}$. Pero, pese a ello, en otras muchas ocasiones la conducta del administrador determinante de que la entidad incurra en infracción no consistirá en su voto en órganos colegiados sino en sus decisiones como órganos unipersonales o en sus meras actuaciones materiales o en su ejecución o apoyo posterior a lo acordado por el órgano colegiado(78); incluso en su mera pasividad, acaso por desconocimiento negligente, de lo que hacían otros directivos.

e) Si son varios los administradores responsables, normalmente cada uno sufrirá una sanción individual y adecuada a su posición y participación ${ }^{(79)}$.

f) En caso de que el administrador sea, a su vez, una persona jurídica (como permite, por ejemplo, el artículo 212.1 del TR de la Ley de Sociedades de Capital (R. Decreto Legislativo 1/2010), será esta la que sufra la sanción prevista para los administradores sin que, a falta de previsión legal, pueda hacerse responsable a las personas físicas que dirijan o gestionen a esta otra entidad.

En todos estos casos, hay un cierto parecido con la situación que ahora ofrece el Derecho Penal para los supuestos de responsabilidad de las personas jurídicas pues en ambos órdenes se castiga a estas y sus administradores. Pero sigue habiendo diferencias notables: en Derecho Penal se considera que el ilícito lo han cometido esas personas físicas, aunque también se hace responsable a la correspondiente persona jurídica; por el contrario, en los casos ahora analizados se parte de que es la persona jurídica la que ha cometido la infracción administrativa y la responsable a la que, por ello, se imponen las sanciones más graves, solo que además, eventualmente, se sanciona también al administrador.

Esta acumulación de sanciones a la persona jurídica y a su administrador suscita algunos reparos. Aunque se explique, como hemos hecho, que se hace responsable al administrador como partícipe en la infracción de la entidad, no puede dejar de detectarse una contradicción: si se dice que es responsable la persona jurídica porque no cabe distinguir entre su voluntad y acción y la voluntad y acción de quienes ocupan sus órganos, sancionar también a estos es desandar el camino andado para imputar la infracción a aquella. O una cosa o la otra, pero no ambas (Suay 1994, 2607) ${ }^{(80)}$ : o se acepta

(77) Por ejemplo, artículo 79.2 de la Ley de Telecomunicaciones de 2014: "Quedan excluidas de la sanción aquellas personas que, formando parte de los órganos colegiados de administración, no hubieran asistido a las reuniones o hubieran votado en contra o salvado su voto"; en la misma línea y con alguna otra causa de exclusión de la responsabilidad, artículos 104.2 de la Ley 10/2014 de Entidades de Crédito, 191.2 de la Ley 20/2015 de Entidades Aseguradoras y 271.3.2 ${ }^{\circ}$ del Texto Refundido de la Ley del Mercado de Valores (R. Decreto Legislativo 4/2015).

(78) Me parece que podrían trasladarse aquí las soluciones del Derecho Penal en las que se da menos importancia al acuerdo de los órganos colegiados y al sentido del voto emitido (que podría ser considerados actos preparatorios impunes) y más al comportamiento posterior, incluso de los que votaron en contra, en fase de ejecución del acuerdo. Sobre ello véase J. M. Zugaldía Espinar, La responsabilidad criminal de las personas jurídicas, de los entes sin personalidad y de sus directivos (Valencia: Tirant lo Blanch, 2013), 45-7.

(79) Habla la Ley de Defensa de la Competencia de “(...) multa... a cada uno de los representantes legales o a las personas (...)”. La misma solución hay que admitir con carácter general salvo que de la ley se dedujera inequívocamente lo contrario. A este respecto, es particularmente interesante la SAN de 20 de mayo de 2002 (Rec. 365/1999).

(80) De hecho, es la solución que acoge la Ley de la Potestad Sancionadora del País Vasco en su artículo 9.3 que, tras establecer que en el caso de las personas jurídicas el juicio de culpabilidad se hará respecto de las personas físicas que hayan formado su voluntad, dice que "en estos casos, no se podrá sancionar, por la misma infracción, a dichas personas físicas". Véase I. López Cárcamo e I. Lasagabaster Herrarte, "Artículo 9. Autoría”, en Ley de la Potestad Sancionadora. Comentario sistemático, coord. Lasagabaster (Bilbao: IVAP, 2006), 198. 
la ficción de la persona jurídica y la imputación orgánica $y$, en consecuencia, se la hace responsable por lo que ha hecho la persona física de su administrador, o se prescinde de tal ficción y entonces solo se sanciona a la persona física del administrador. Pero parece incongruente asumir simultáneamente ambos planteamientos para sancionar a la entidad y a su administrador. Hasta podría sostenerse que, en el fondo, se vulnera el non bis in ídem con el artificio de imputar una única conducta de un único sujeto a dos personas distintas ${ }^{(81)}$. Ningún tribunal lo ha entendido así y se acepta sin problemas esta acumulación de responsabilidad societaria e individual, tanto en estos casos analizados de Derecho Administrativo sancionador como en los que ahora conoce, aunque con otra modalidad, el Derecho Penal. Digamos que se está dispuesto a aceptar sin escrúpulos estas incongruencias y la correspondiente matización al non bis in ídem; pero reconozcamos, al menos, que son tales.

Pese a reconocer lo anterior, ¿está justificado este sistema? ¿Lo está que se establezca en algunas leyes y no en otras? En algunos sectores del ordenamiento, como el de las entidades de crédito o de seguros o similares, la doble responsabilidad tiene una justificación específica en tanto que la ordenación pública gravita en gran medida en torno a la confianza en sus administradores, en su probidad(82). Fuera de esos ámbitos se ha negado la justificación y la conveniencia de este sistema de responsabilidad acumulativa (Baño León
1996, 254-5). Sin embargo, ya apuntamos antes que la exclusiva responsabilidad sancionadora de las personas jurídicas dificultaba a veces que las sanciones cumplieran sus funciones y, en coherencia, digamos ahora que esta responsabilidad simultánea de la persona jurídica y de sus administradores palia aquellas insuficiencias y refuerza las funciones de retribución y de prevención que deben cumplir las sanciones. Lo correcto es buscar una solución que logre las ventajas de esta doble responsabilidad, las generales y las específicas en ciertos sectores, con los mínimos inconvenientes. Ese punto de equilibrio, que cabría plasmar en una ley básica general, podría consistir en admitir como excepción la responsabilidad acumulativa de los administradores cuando se dieran ciertas condiciones. Algunas ya se desprenden de lo explicado y son solo consecuencia de los principios de legalidad, culpabilidad y personalidad: que tal responsabilidad la establezca una ley sectorial; y que se circunscriba a los casos en que el administrador haya contribuido con una conducta propia dolosa o negligente (quizá, incluso solo con negligencia grave) a

(81) En ese sentido, B. Lozano Cutanda, voz "Persona jurídica, sujeto activo y responsable de las infracciones administrativas", en Diccionario de sanciones administrativas (Madrid: Iustel, 2010), 605-8. Nunca ha visto ningún tribunal vulneración del non bis in ídem en estos supuestos en que la misma ley prevé sanción para la persona jurídica y para sus administradores. Véase L. Alarcón Sotomayor, La garantían non bis in ídem y el procedimiento administrativo sancionador (Madrid: lustel, 2008$), 42$. A. Torío, "Injusto penal e injusto administrativo (presupuestos para la reforma del sistema de sanciones", en Estudios sobre la Constitución Española, homenaje al Profesor Eduardo García de Enterría. Tom. III. (Madrid: Civitas, 1991), 2544, no ve ningún inconveniente a la imputación simultánea de la misma infracción a la persona jurídica y a quienes actuaron en su nombre. Expresamente niega esta vulneración P. Mayor Menéndez, "Sobre la responsabilidad conjunta de las personas jurídicas y sus administradores en el Derecho Administrativo sancionador (especial referencia al Mercado de Valores)", Revista Española de Derecho Administrativo 87 (1995): 357, no solo por no existir identidad de sujetos sino tampoco de fundamento "pues en cada caso se habrían vulnerado obligaciones distintas". Véase también A. Nieto, Derecho Administrativo sancionador, $5^{\text {a }}$ ed. (Madrid: Tecnos, 2012), 410, así como Manuel Gómez Tomillo e Iñigo Sanz Rubiales. Derecho Administrativo sancionador. Parte general. Teoría general y práctica del Derecho Penal Administrativo, $2^{a}$ ed. (Aranzadi, 2010), 234-5. Formalmente, estos argumentos son aceptables y explican que nunca se haya visto en esta duplicidad de responsabilidades violación del non bis in ídem. Pero materialmente es más discutible y en algún caso podrían resultar injusticias notorias. Piénsese en una sociedad unipersonal en el que el único socio fuese, además, su administrador.

(82) Véase, en el estudio preliminar de la obra colectiva dirigida por él mismo, T. R. Fernández, Comentarios a la Ley de Disciplina e Intervención de las Entidades de Crédito (Madrid, 1989), 19-20; y en la misma obra J. Suay Rincón, en el comentario al artículo 15, páginas 64-6. 
Responsabilidad sancionadora de personas jurídicas, entes sin personalidad y administradores

Disciplinary Liability of legal entities, entities without personality and administrators

la comisión de la infracción por la persona jurídica. Y además podría imponerse que las sanciones previstas para el administrador sean de las que únicamente él, no la entidad, pueda sufrir (así, destacadamente la suspensión o inhabilitación para ocupar cargos similares). Si se trata de imponerles multas, bastaría (y es más razonable) concentrarlas en la persona jurídica, sin perjuicio de su acción de regreso contra el administrador. Como mínimo, si se aceptara esa posibilidad de imponer multas a ambos, sería oportuna una regla semejante a la del artículo 31 ter 1 in fine del Código Penal que permite al juez "modular las respectivas cuantías, de modo que la suma resultante no sea desproporcionada en relación con la gravedad" de los hechos.

\section{Referencias Bibliográficas}

Baño León, J. M. 1996. Potestades administrativas y garantías de las empresas en el Derecho español de la competencia. Madrid: McGraw-Hill.

Quintero Olivares, Gonzalo. 1991. La autotutela, los límites al poder sancionador de la Administración pública y los principios inspiradores del Derecho Penal. Revista de Administración Pública 126: 253-96.

Suay Rincón, J. 1994. Algunas consideraciones en torno a la aplicación de los principios de la responsabilidad personal (o por actos propios) y de culpabilidad en el Derecho administrativo sancionador. En la obra colectiva Estudios de Derecho bancario y bursátil, homenaje a Evelio Verdera y Tuells. Madrid: La Ley, 2607. 